\title{
ISTORICUL CERCETĂRILOR ASUPRA CERAMICII ROMANO-BIZANTINE DIN DOBROGEA
}

Alexandru Bădescu

\section{BACKGROUND RESEARCH ON THE ROMAN-BYZANTINE POTTERY FROM DOBROGEA}

The author is trying to do a retrospective over the articles and the books about late Roman pottery from Dobrogea, and he is concluding some aspects about the way of the publications, and also about the quantity and the important of the Roman pottery studies in the last three decades.

Between word interwar's times there were only few ceramic artifacts published by Vasile Pârvan. This stage is characterized by lack of interest for pottery.

At the end of the $5^{\text {th }}$ decade and till the beginning of the $6^{\text {th }}$ of the last century, the pottery was infrequent mentioned in the annually archeological reports, the pottery is rare mentioned artifacts, and only like large categories or the remarkable pieces.

Alter 1960 there were many archeological researches and an important part of the archeological material was published. Many of the archeological excavation had a rescue character, because in Romania, in that time, there were a lot of buildings constructions.

After 1990. a lot of articles and books about Roman pottery there published, but not only the number has rise, but also the methodology of ceramic studies. Taking in account the archeological sites and the publication about Roman pottery from Lower Danube, the number of the publication from Dobrogea is a very large one, but there are still some important gaps between the Mediterranean arias and the Pontics one.

Kcywords: study, late Roman pottery, Dobrogea.

Cuvinte cheic: studiu, ceramică romano-bizantină, Dobrogea.

Dobrogea, integrată mai devreme în Imperiul Roman şi supusă unor forme variate de influenţă datorită poziţiei sale, este, comparativ cu zona Dunării de Jos, cel mai intens cercetat teritoriu carc a lăcut parte din Imperiu. Acest dezechilibru are motivaţii legate atât de trecutul zonei amintite (aflată în atenţia administraf̧iei imperiale din perioada târzie pentru că a fost permanent parte integrantă a imperiului şi a avut o densitate de locuitori net superioară zonei nord-dunărene), cât şi de prezentul ei (stadiul cercetărilor este mult avansat în zona dobrogeană). Pentru Dobrogea cxistă două monografiii de sit apărute în primii ani ai acestui mileniu', datorate lui Fl. Topoleanu şi I. C. Opriş, la acestea adăugându-se contribuţiile semnate de Al. Suceveanu ${ }^{2}$, C-tin Scorpan ${ }^{3}, \mathrm{Al}$.

\footnotetext{
Topoleanu 2000: Opriş 2003.

- Suceveanu 1979: Suceveanu 1982: Suceveanu, Scorpan 1971.

3 Scorpan 1972: Scorpan 1972a: Scorpan 1973: Scorpan 1973a: Scorpan 1973b: Scorpan 1975: Scorpan 1976: Scorpan 1977: Scorpan 1977a: Scorpan 1978.
}

Rădulescu', Gh. Papuc ${ }^{5}, \mathrm{~V}$. Lungu$^{6}, \mathrm{M}$. Bucovală $^{7}$, O. Bounegru", M. Irimia', V. H. Baumann $^{10}$, A. Opaił ${ }^{\prime \prime}$, şi mulţi alţii, pe care îi vom aminti în rândurile de mai jos. Foarte importante sunt şi lucrările dedicate ceramicii romane timpurii de la Histria (com. Istria, jud. Constanţa) ${ }^{12}$ şi Durostorum (com. Ostrov, jud.

4 Rădulescu 1966; Rădulescu 1969: Rădulescu 1973: Rădulescu 1973a; Rădulescu 1975: Rảdulescu et alii 1973: Rādulescu. Scorpan 1975.

${ }_{5}^{5}$ Papuc 1973: Papuc 1976: Papuc. Munteanu 1976.

${ }^{6}$ Lungu. Bouncgru, Avram 1984: Lungu, Bounegru, Avram 1990.

${ }^{7}$ Bucovalā 1984: Bucovală 1993: Bucovalã, Paşca 1989: Bucovală. Paşca 1991

${ }^{8}$ Bounegru 1989; Bounegru 2001.

9 Irimia 1981

10 Baumann 1980: Baumann 1984: Baumann 1984a; Baumann 1991: Baumann 1991a: Baumann 1991b; Baumann 1995: Baumann 1997.

11 Opait 1979: Opait 1980; Opait 1980a: Opaiţ 1984: Opait 1985: Opaiţ 1987: Opait 1987a: Opait 1991; Opait 1991a; Opait 1991b; Opait 1991c: Opait 1996; Opaił 1998; Opait 1998a: Opaił 2000: Opait 2002: Opaił 2004: Opaił. Sion. Vasiliu 1980: Opaił̧, Zahariade 1980; Opaiţ. Opaiţ, Bănică 1990: Opai! 1977.

12 Suceveanu 2000. 
Constanţa $)^{1.3}$ care, chiar dacă sunt în afara perioadei aflate în atenţia noastră, pot fi studiate împreună cu cele dedicate materialului ceramic romano-bizantin pentru a creiona o imagine reală în legătură cu aspectele de ordin economic, administrativ sau militar. Spre exemplu, pot fi trase concluzii în privinţa formelor ceramice din secolele I-III p. Chr. când se constată influențe elenistice, pentru ca, începând cu sfârşitul secolului al III-lea şi până în secolul al VIl-lea p. Chr., să fie clară influenţa romanā'l ${ }^{-4}$. Așezările din Dobrogea, începând cu cele de pe litoral şi continuând cu cele din interior sau de pe limes-ul dunărean, de la Durostorum până la vărsarea fluviului în mare, trebuie să fie tratate împreună pentru că erau integrate, din punct de vedere economic, administrativ şi militar, în acelaşi spaţiu - colţul de nord-est al imperiului ${ }^{15}$.

Cantitatea de material ceramic rezultat in urma cercetărilor arheologice organizate în Dobrogea vrcme de peste 90 de ani este considerabilă, astfel că este normal ca numărul studiilor dedicate acestui artefact să fie pe măsură. Dacă în perioada 1914-1949 ceramica nu constituia o prioritate, după anul 1950 sunt tot mai multe referirile despre materialul ceramic în lucrări monografice, studii sau rapoarte de săpătură $^{16}$, schimbarea fiind legată de noua strategie de cercetare a siturilor dobrogene pe care a impus-o Academia Română.

La începutul deceniului al şaselea al secolului trecut V. Canarache a descoperit, în zona actualului sat Sinoe (jud. Constanţa), o aşezare romană în care a făcut câteva sondaje. Situl respectiv, intrat în literatura vremii sub numele de ,Sinoe-Vicus”, avea cel puţin un nivel de locuire romano-bizantină, în care a fost descoperit material ceramic datat de autorul săpăturilor în secolele V-VI p. Chr. ${ }^{17}$

Începute în anul $1914^{18}$ şi continuate după 1949 cu o altă strategic, cercetările arheologice de

\footnotetext{
13 Mușeleanu 2003.

1.1 Rädulescu 1975. 332.

${ }^{15}$ Rãdulescu 1973. 129.

16 Plorescu 1955. 338-342: Condurachi et alii 1959. 278280: Condurachi et alii 1960, 232, 240, 242.

${ }^{17}$ Canarache 1953. 136-138.

18 În anul 1914 V. Pârvan publica primele artelacte descoperite la Clmetum: Pârvan 1914. pl. XXX.
}

la Histria au dus la aparił̧ia unui număr important de studii începând cu deceniul al şaselea al secolului trecut. Astfel, în anul 1955 R. Florescu publică trei fragmente ceramice pe care erau incizate o pasăre şi un diavol ${ }^{19}$. Câtiva ani mai târziu, Em. Condurachi prezintă în volumul Histria o mică parte din vasele de mari dimensiuni, amforele şi oalele descoperite până atunci în acelaşi $\operatorname{sit}^{20}$. Tot domniei sale $i$ se datorează şi publicarea unor vase romane târzii în rapoartele privind săpăturile de la Histria din anii 1959 şi $1960^{21}$.

În anii 1954-1955 Ex. Bujor, care a făcut săpături de salvare în cele două cimitire de incineraţie de la Murighiol (jud. Tulcea), prezintă pe scurt rezultatele săpăturii pe care a realizat-o în interiorul fortificaţiei romane şi menţionează existenţa unui strat de $20 \mathrm{~cm}$ în care sunt foarte multe fragmente ceramice, majoritatea de la amfore, databile în secolele IV-V sau chiar VI p. $\mathrm{Chr}^{22}$ La doi ani după publicarea precedentului articol acelaşi autor prezintă dezastrul pe care-l produceau localnicii în căutarea materialului litic şi aminteşte descoperirea a numeroase fragmente de amfore şi oale databile în secolele V-VI p. Chr. ${ }^{23}$

Începând cu deceniul al şaptelea al secolului trecut au fost publicate studii tot mai specializate, dedicate unei categorii ceramice sau întregului material ceramic descoperit. Datorită interesului manifestat pentru o anumită perioadă istorică, mă voi referi doar la contribuţiile care au ca obiect de studiu ceramica romano-bizantină.

În anul 1965 a apărut un articol dedicat ceramicii romane târzii cu decor ştampilat în care autorul, l-am numit aici pe Em. Popescu, a prezentat tot materialul de acest tip descoperit la Histria în perioada ante şi post $1949^{24}$. Datorită faptului că ceramica descoperită înainte de 1949 nu era însoţită de date stratigrafice dar avea caractere comune cu cea din zona orientală a imperiului, autorul a folosit pentru cronologie şi tipologie studiile care prezentau acest gen de

\footnotetext{
${ }^{19}$ Popescu 1965. 695. nota 2.

${ }^{20}$ Condurachi $1959,451-465$.

21 Condurachi et atii 1959. 278-280; Condurachi et alii 1960. 232, 240, 242

${ }^{22}$ Bujor 1958, 373-378

${ }^{23}$ Bujor 1960. 297-300

${ }^{24}$ Popescu 1965, 695-724.
} 
material ceramic descoperit la Athena şi Antiohia, singurele situri unde se făcuseră cercetări sistematice bazate pe stratigrafie ${ }^{25}$. Autorul stabileşte, în funcţie de ornamentaţie, trei categorii de ceramică romană târzie cu decor ştampilat: cu desene simple sau vegetale, cu desene umane sau animaliere şi cu simboluri creștine.

După ce, în anul 1964, fusese descoperit la Altinum (Com. Oltina, jud. Constanța), lângă punctul numit „La dinamită”, un singur cuptor de ars ceramică, în 1967 au fost cercetate trei asemenea cuptoare ${ }^{26}$. Din păcate cercetările arheologice nu au fost continuate de alte sondaje, cu toate că locuitorii spuneau că mai avuseseră parte de asemenea descoperiri. În cuptorul nr. 1 a fost descoperită ceramică romană târzie fragmentară (două amfore întregibile —una globulară şi alta „cu coaste"- datate în sec. V-VI p. Chr. $)^{27}$. Materialul ceramic descoperit în cuptorul nr. 2, situat la $40 \mathrm{~m}$ nord-vest de primul, în marginea şoselei, compus din amfore cu striuri orizontale, amfore „,cu coaste", oale borcan şi trei opaiţe, a fost datat în secolele V-VI p. Chr. ${ }^{28}$ Situaţia s-a repetat şi la cuptorul nr. 3, în care fragmentele de amfore cu striuri orizontale, uşor ondulate, amfore „,cu coaste”, oale borcan şi căniţe au primit o datare la fel de largă din partea autorului săpăturiii ${ }^{29}$.

În acelaşi an a fost publicat un studiu, semnat dc C-tin Scorpan, în care crau prezentate, pe lîngã materialul ceramic carpic şi trei vase ${ }^{30}$ pe carc autorul le crede imitaţii locale ale unor forme locale sau legate de cultura Chilià-Militari din Muntenia şi le datează în secolul al III-lea p. Chr. ${ }^{\text {.1 }}$ Patru ani mai târziu, M. Comşa a publicat

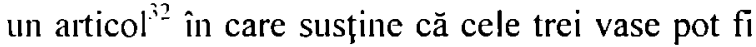
posterioare secolului al III-lea p. Chr. şi că primcle două sunt imitaţii locale după forme romane.

\footnotetext{
25 Popescu 1965.697.

26 Irimia 1968. 379-408.

O amforā globulară asemănătoare a lost datată la Dinogetia in secolul al II-lea p. Chr., insã la Altinum (Olina. jud. Constanła) a fost descoperită în praefurnium alături de amlora ..cu coaste” (Irinia 1968. 395). Poate fi vorbal de continuarea unei lorme amforice mai vechi.

${ }^{28}$ Irimia 1968, 401.

2.) Irimia 1968, 403.

"Scorpan 1968. lig. 19. 20. 361: lig. 3 a-b. 347

il Scorpan 1968. 341-361.

i2 Comsia 1972. 223. 234.
}

Un obiectiv arheologic interesant, datorită materialului târziu descoperit, este casa romană de la Dinogetia ${ }^{33}$, o construcţie de mari dimensiuni, care a aparţinut foarte probabil unui personaj cu funcţie militară sau civilă importantă $\breve{34}^{34}$. Clădirea, asemănătoare cu cele descoperite la Histria ${ }^{35}$, a fost locuită, cu mici modificări, intre secolul al IV-lea şi mijlocul secolului al VI-lea p. Chr. Între prima şi a doua fază, mult restrânsă, casa a fost părăsită timp de aproape o sută de ani. Materialul ceramic, în mare parte fragmentar şi puţin numeros, este databil o parte în secolul al IV-lea, iar cealaltă parte între sfârşitul secolului al V-lea şi jumătatea secolului al VI-lea. Şi în acest caz, fragmentele de amfore sunt cele mai numeroase ${ }^{36}$.

Pe lângă materialele descoperite în săpături sistematice sau de salvare, au fost publicate şi unele descoperite întâmplător sau în timpul perieghezelor. Dintre cele descoperite la Pârjoaia (jud. Constanţa) şi publicate de V. Culicăa ${ }^{37}$, se remarcă două opaiţe ${ }^{38}$, unul întreg (întâlnit până în secolul al IV-lea p. Chr.) şi un fragment din partea superioară a altuia (datat în secolele V-VI p. Chr.).

După anul 1980 au urmat două decenii cu descoperiri multe şi importante, datorate în primul rând săpăturilor sistematice dar şi celor de salvare ${ }^{39}$, cantitatea de ceramică, inclusiv romanobizantină, fiind făă precedent şi numărul studiilor pe măsură.

\footnotetext{
${ }^{33}$ Barnea $1969,245-266$.

${ }^{34}$ Barnea 1969, 265

${ }^{35}$ Stoian 1953.

${ }^{36}$ Multe amfore au în zona umărului litere grecești incizate (Barnea 1969, 255, fig. 6/4) sau scrise cu vopsea roşic (Barnea 1969, 255, fig. 6/2:264, 12/1-3), urmalc de vasecăni, oale. castroane (Inajoritatea din pastă zgrunı̧uroasã; Barnea 1969. 259, lig. 9/1-3, 7-12), capace (Barnea 1969. 262. lig. $10 / 8 ; 259,9 / 4-6,13-17$ ) si opaite (Barnea 1969. 262, fig. 10/1-7).

${ }^{37}$ Culică 1969.

38 Analogii la: Iconomu 1967, nr. 753, fig. 170; Constantinescu 1967. 5 (dacã opaiţul este datat in secolul al III-lca p. Chr. este cxclus caracterul creștin al acestuia pentru că nu există dovezi arheologice creștine anterioare secolului al IV-lea p. Chr.; oricum acest lip de opai\} este întâlnit pânã la începutul secolului al IV-lea p. Chr.): Tudor 1953. 712, ligg. 12/e (un opaił asemănător, descoperit la Sucidava. are acelaşi semn pe revers și a lost datat in secolele IV-V p. Chr.).

39 Datoratc. în special. lucrărilor edilitare din oraşelc Constanła (Tomis) și Mangalia (Callatis)
} 
Primul din lunga listă a contribuţiilor amintite este articolul semnat de N. Hamparţumian care a publicat rezultatele cercetărilor realizale între anii 1961-1964 în zona bazilicii „extra muros" de la Histria, unde există o necropolă romană târzie. Din păcate, cele 90 de morminte descoperite, 16 în anii 1955-1956 şi 74 în perioada $1961-1964^{40}$, au inventar foarte modest, constituit din fibule, brăţări, monede şi ceramică. Foarte curios este faptul că ceramica formează cca mai rară categorie descoperită în această necropolă, autorul prezentând numai trei vase intregi databile în secolul al IV-lea p. Chr. ${ }^{41}$ Chiar dacă nu poate fi precizată populaţia îngropată în această necropolă ${ }^{-42}$, este clar că majoritatea barbarilor stabiliţi la Histria şi-au însuşit formele de cultură şi civilizaţie romană. Acest fapt explică de ce sub forme romane se poate ,ascunde" o populaţie barbară, putemic romanizată ${ }^{43}$.

Edificiul roman cu mozaic de la Tomis, descoperit în anul 1959, reprezintă o şansă rară oferită ceramiştilor pentru că materialul arheologic din cele 11 magazii este foarte important datorită condiţiilor de descoperire, a cantităţii acestuia, precum şi a informaţiei istorice care poate fí obţinută în urma prelucrării şi publicării luii. $O$ parte importantă a ceramicii descoperite in acest punct a fosı prelucratã şi publicatã de $\Lambda$. Rădulescu ${ }^{4 \cdot 4}$ şi Gh. Papuc ${ }^{45}$. Ccramica romană târzie cu decor ştampilat a fost descoperită în multe puncte de pe teritoriul Dobrogei $^{46}$ (Tomis, Carsium ${ }^{47}$, Sacidava ${ }^{48}$, IIistria, Tropaeum Traiant" ${ }^{49}$, Dinogetia ${ }^{50}$, Salsovia, Piatra Frecăţei ${ }^{51}$ ), motiv pentru care a lost în atenţia multor arheologi care au publicat asemenea materiale sau au amintit existenţa acestora in alte puncte din Dobrogea ${ }^{52}$. Într-un

\footnotetext{
40 Nubar 1971.

1 A rost descoperită ceramicã din secolul al IV-lea p. Chr. in mormintele nr. 12, 29 si 32.

42 Sarmalică sau alanicã.

4. Nubar 1971. 214.

4.4 Rădulescu 1973a: Rădulescu 1975.

45 Papuc 1973: Papuc 1976

4 "Papuc 1973, 154, notele 4-11.

"lầrşova. jud. Constanł̧a.

${ }^{48}$ Mârlcanu. com. Dunăreni. jud. Constanţa.

19 Adamclisi, jud. Constanţa.

${ }^{50}$ Garvän. com. Jijila. jud. Tulcea

51 Ostrov, jud. Tulcea.

52 Lambrino 1931: Ştefan 1947, 305-307; Stelan el alii
}

studiu semnat de Gh. Papuc sunt publicate 114 fragmente de ceramică ştampilată (întâlnită în zona răsăriteană a Imperiului), pe care autorul le împarte în trei grupe, în funcţie de datare şi decor. Principala concluzie este că în Tomis, sau în împrejurimi, a existat un atelier care a produs asemenea ceramică ${ }^{53}$.

Referitor la cercetările de la Edificiul cu mozaic, Al. Rădulescu amintește că în campaniile dintre anii 1965-1968 au fost descoperite în încăperile boltite (nr. 3 şi 4) aproape 120 de amfore întregi sau fisurate ${ }^{54}$. Dintre acestea, 29 au în partea superioară, scrijelate sau pictate, semne grafice. Primele sunt cifre în caractere latine, exclusiv asociaţii din semnele $\mathrm{X}$ şi I, iar celelalte, pictate cu vopsea roşie, sunt litere greceşti care indică tot cifre ${ }^{55}$. Sunt amintite şi descoperirile de la Callatis $^{56}$, Capidava ${ }^{57}$, Histria ${ }^{58}$, Tomis (altele decât cele de la Edificiul cu mozaic) ${ }^{59}$, Ulmetum ${ }^{60}$ şi Jurilovca ${ }^{61}$. Articolul lui Al. Rădulescu a adus în atenţia specialiştilor, în urmă cu peste 30 de ani, importanţa metrologiei pentru arheologie. Publicarea întregului material ceramic descoperit la Edificiul roman cu mozaic poate aduce informaţii multe şi importante legate de viaţa economică a Tomis-ului din perioada secolelor IV-VI p. Chr. şi nu numai.

Acelaşi autor, împreună cu alţi patru colegi constănł̧eni ${ }^{-2}$, a publicat și rezultatele cercetărilor arheologice efectuate, în anii 1971-1972, în parcul de pe faleza din Constanta ${ }^{63}$. Materialul ceramic acoperă perioada dintre secolele $\mathrm{V}$ a. Chr. şi VI p. Chr., dar cel descoperit în canalul de pe axa străzii A este romano-bizantin, majoritatea

1951, 37; Ştefan, Barnca. Mitrea 1962, 678: Barnea 1968. 493: Barnca 1969. 255-263: Aricescu 1971. 355: Scorpan 1972; Popescu 1965.

53 Papuc 1973. 190.

54 Rădulescu 1973a. 194.

${ }^{55}$ Rādulescu 1973a, 201

${ }^{56}$ Iconomu 1968, 262-264. fig. 11-13.

${ }^{57}$ Florescu 1967, lig. 22.

${ }^{58}$ Histria. I, 458. lig. 383, 384.

${ }^{59}$ Rādulescu 1973a, 200.

${ }^{60}$ Pârvan 1974. 149, lig. 74 (în ediţia din 1974, 96. fìg. 74. sunt prezentate alte liagmente ceramice).

${ }^{61}$ Descoperire izolală: Rădulescu 1973, 200.

${ }^{62}$ Al. Rădulescu, C-tin Scorpan, Gh. Papuc, E. Coman. C. Stavru.

${ }^{63}$ Unul dintre locurile puţin afectate ale anticului Tomis. astlè că efectuarea unor săpături arheologice acolo se impunea. Suprafał̨a cercetată a fost de cca. $600 \mathrm{~m}^{2}$. 
datat în secolele V-VI p. Chr. ${ }^{64}$ Autorii nu prezintá în articolul amintit decât douã vase întregibile, dar importantă este cantitatea mare de ceramică descoperită cu acest prilej. Al. Rădulescu şi C-tin Scorpan revin cu date noi legate de cercetările arheologice din Parcul Catedralei ${ }^{65}$, subliniind că ceramica romano-bizantină descoperită în canalele celor două străzi ${ }^{66}$, în gropile şi straturile de umplutură, este foarte numeroasă ${ }^{67}$. Nu știm câtă ceramică a fost descoperită, dar este de presupus că lotul este impresionant pentru că suprafạa cercetatã este $700 \mathrm{~m}^{2}$.

În perioada cuprinsă între anii 1967 şi 1976 C. Iconomu a publicat o lucrare şi două articole dedicate opaiţelor şi tiparelor de opaiţe descoperite la Tomis ${ }^{68}$.

Într-un alt articol $^{69}$ din anul 1973 C-tin Scorpan publică nouă vase și fragmente ceramice romane târzii ${ }^{70}$, pe care le prezintă ca având „un caracter special" ${ }^{, 71}$. Sunt amintite şi alte două descoperiri remarcabile: o locuinţă cu ,.pavaj de cărămizi, înconjurat de un zid rudimentar și neregulat, fără fundaţie" ${ }^{\text {,72 }}$, ambele atestând niveluri de locuire care suprapun incinta demantelată şi au fost datate la începutul secolului al VII-lea p. Chr. Cu siguranţă că materialul ceramic descoperit în aceste puncte este interesant de văzut şi publicat, ca de altfel tot materialul roman târziu de Saciclava.

În acelaşi an, C-tin Scorpan a semnat un alt studiu $^{73}$ in care prezintă şi clasifică opaiţele din siturile dobrogene $e^{7.1}$ în trei mari tipuri. Tot aici amintește modalităţile de producere a lucernelor ${ }^{75}$, prezintã obiecte din toate categoriile, după care discută despre datarea şi provenienţa

\footnotetext{
${ }^{6+1}$ Rădulescu ef alii 1973.

${ }^{65}$ Rãdulescu. Scorpan 1975.

${ }^{60}$ Strada. gropile şi straturile de umplutură sunt datate în secolul al VI-lea p. Chr.

${ }^{67}$ Rădulescu. Scorpan 1975, 11.

${ }^{68}$ Iconomu 1967: Iconomu 1970, 237-253: Iconomu 1976 , 135-146

${ }^{69)}$ Scorpan 1973

${ }^{70}$ Trci amlore intregi. un capac şi o toartă de amforă, un ulcior-amforoidal, două opaiţe și un fragment cu inscripţie incizată în limba greacā.

${ }^{71}$ Scorpan 1973. 320.

${ }^{72}$ Scorpan 1973. 321.

${ }^{73}$ Scorpan 1973a.

${ }^{74}$ Tomis, Callatis. Sacidava. Capidava. Dinogetia.

${ }^{75}$ La roată, cu mâna sau in tipare.
}

opaiţelor, subliniind că există decalaje între zonele din vestul şi estul Imperiului Roman.

După cercetările arheologice efectuate la Tomis, în Edificiul cu mozaic şi în parcul de pe faleză, a urmat descoperirea unui ansamblu funerar familial ${ }^{76}$. Materialul ceramic descoperit în complexul funerar $\mathrm{B}^{77}$, publicat de N. CheluţăGeorgescu $^{78}$, este databil în secolele IV-VI p. Chr. ${ }^{79}$ Un alt complex funerar ${ }^{80}$, format din patru camere dispuse în cruce, a fost publicat de acelaşi autor şi se pare că face parte din ramificaţia subterană surprinsã pe strada Mircea cel Bătrân ${ }^{81}$. În canalul de acces al complexului a fost descoperit un vas ceramic ${ }^{82}$ datat în secolul al VIlea p. Chr. ${ }^{8.3}$

Cu siguranţă că C-tin Scorpan poate fi socotit un deschizător de drumuri în ceramistica românească şi unul dintre cei mai prolifici specialişti în acest domeniu. Într-un alt articol ${ }^{84}$ apărut în_anul 1975 el se încumetă să facă o radiografie a cercetărilor arheologice pe care le raporta la puf̣inătatea materialului ceramic publicat $^{85}$. Cu mici excepţii la acea dată, reprezentate de Histria, Dinogetia, Sacidava şi Piatra Frecăţei, ceramica romano-bizantină era doar amintită ca fiind ,numeroasă”, dar expediată în câteva fraze sau, în cel mai fericit caz, prezentate doar câteva obiecte deosebite. De obicei „şansa" de a fi publicate o aveau materialele cu o plastică interesantă sau cele care erau întregi sau întregibile. Rapoartele de săpătură nu

\footnotetext{
${ }^{76}$ Strada Mircea cel Bătrân.

77 Amlore de mari dimensiuni, fragment de ulcior cu o toartă, fragment de vas cilindric şi un opaiţ.

${ }^{78}$ Chelutăă-Georgescu 1974.

79 Amforele descoperite sunt de două tipuri: unul de mari dimensiuni: pânã la $140 / 30 \mathrm{~cm}$ (de vãzut Coja 1972. 38. fig. $5 / 10$ ), sau de dimensiuni mai mici şi care are înscrisuri cu vopsea neagrā (analogie cu inscripţia de pe un fragment ceramic descoperit la Sucidava: Tudor 1948, 168: Tudor 1948a: Tudor 1953, 168, 700, 706, 710, 712; Barnea 1958, 298. fig. (1). Amforele mari, provenite din nordul Africii, sunt datate in necropolele din Spania în secolul al IV-lea p. Chr. (Vegas 1973. 141. lip 57. fig. 2): Barbu 1971. 53. tip VIII-4, 65, tabel (amfore asemănătoare, descoperite în morminte din Tonis, sunt datate in secolul al V-lea p. Chr.).

${ }^{80}$ Chelułă-Georgescu 1977.

${ }^{81}$ Este la $150 \mathrm{~m}$ nord-est de strada Mircea cel Bătrân.

${ }^{82}$ Vas borcan.

${ }^{83}$ Datarea i se datorează lui C-tin Scorpan (vezi Scorpan 1975, 263-313: 288. tipul C, fig. VIII, 4, XII, 9).

${ }^{84}$ Scorpan 1975.

${ }^{85}$ Scorpan 1975, 264.
} 
conţineau, de obicei, datele stratigrafice şi condiţiile de descoperire amănunţite, iar ceramica era tratată în cadrul unor grupe tipologice mari şi nu individual. În asemenea condiţii, era complicat de stabilit clasificări în funcţie de cronologie, tipologia formelor sau a pastelor şi, evident, nu puteau fi sesizate modificările survenite în timp pentru o anumită categorie ceramică. Autorul face o clasificare tipologico-cronologică a categoriilor ceramice $^{80}$, stabilind tipuri şi variante pentru fiecare dintre ele, şi abordează problema ceramicii locale susţinând că, spre deosebire de amfore, majoritatea ceramicii de uz comun era de producţie locală, realitate constatată şi la Iatrus

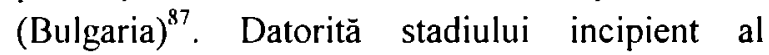
cercetărilor, autorul se limitează să constate invocând descoperirile de la Histria- că ceramica romano-bizantină a avut, cu mici exceptii, un anumit standard de calitate care nu a coborât sub linia medie până la începutul secolului al VII-lea p. Chr. ${ }^{88}$ Articolul lui C-tin Scorpan este primul mare studiu dedicat ceramicii romano-bizantine dintr-un sit în care se apelează şi la analogii din zona limes-ului sau chiar din toată Scythia Minor. Au urmat apoi alte câteva studii comparative cu acesta ${ }^{89}$ sau, beneficiind de alte descoperiri şi loturi ceramice publicate, chiar mai amănunţite ${ }^{90}$.

Alt mare ceramist constănţean, Al. Rădulescu, publica în acelaşi an (1975) un articol dedicat chiar ceramicii de uz comun din Scythia Minor ${ }^{91}$, la care făcea referire C-tin Scorpan în rândurile de mai sus. Chiar dacă, cu mici excepţii ${ }^{92}$, tipurile ceramice prezentate sunt timpurii, articolul este de reţinut pentru că autorul discută problema decăderii meşteşugurilor ceramice pe care o vede ca fiind urmarea fireascã a instabilităţii din perioada cuprinsă între secolul al IV-lea şi secolul al VII-lea p. Chr., motivul principal care a dus la dispariţia treptată a tipurilor de vase mai mici ce necesitau atenţie şi îndemânare pe măsură. Concluzia sa este

\footnotetext{
${ }^{86}$ Amlore. ulcioare, oale. căni. farfurii, platouri și opaite.

${ }^{87}$ Scorpan $1975,292$.

${ }^{88}$ Scorpan $1975,295$.

${ }^{80}$ Popilian 1976

"So Suceveanu 1982: Baumann 1991a: Opail 1991: Opait 1991 a: Topoleanu 2000: Opriss 2003.

"Rădulescu 1975.

"Y Un tip de ulcior şi unul de unguentarium întâlnite şi în sccolele al IV-lea, respectiv al V-lea p. Chr.
}

că între secolele al IV-lea şi al VII-lea p. Chr. majoritatea aşezărilor din interiorul provinciei Schytia Minor şi de pe limes nu mai aveau condiţiile economice minimale pentru producerea ceramicii, amforele fiind un argument puternic în acest sens. Cu siguranţă că ceramica uzuală se va fi produs în continuare, evident într-o manieră mai grosieră şi mult simplificată din punct de vedere al formelor şi pastei ${ }^{93}$. Oricum, chiar şi în siturile de pe litoral s-a constatat că importurile de ceramică, chiar şi de uz comun, erau foarte importante, iar motivul este legat de constatarea de mai sus şi de raportul calitate-preţ. Va fi interesant de văzut cât la sută reprezintă importurile şi cât producţia ceramică locală în siturile de pe limes, din interior sau de pe litoral ${ }^{94}$.

În anul 1976 Al. Rădulescu recidivează cu un articol referitor la amforele romane şi romanobizantine din Scythia Minor ${ }^{95}$, in care argumentează importanţa studiilor de acest gen prin faptul că ceramica reprezintă peste $90 \%$ din materialul descoperit în timpul cercetărilor arheologice, iar amforele constituie, de obicei, peste jumătate din totalul ceramicii dintr-un sit. Semnele de întrebare legate de acest tip de recipiente se referă la locul de fabricare, conţinut şi datare. Cât privește prima problemă poate fi rezolvată prin analizele chimice şi petrologice ale fragımentelor ceramice, singura condiţie fiind existenţa analizelor pentru argila din zonele producătoare de ceramică. În acest mod pot fi despărţite importurile de producţia locală pentru că, de obicei, cele din urmă sunt imitaţii după tipurile aflate în circulaţie. În legătură cu datarea există, ca la mai toate tipurile ceramice, decalaje între zonele orientale sau occidentale şi chiar în interiorul acestora, astfel că argumentul esenţial pentru o încadrare corectă trebuie să fie contextul stratigrafic în care a fost descoperit materialul ceramic. Referitor la marfa transportată în aceste recipiente, este normal ca ,ambalajul” să fie potrivit pentru scopul creării lui şi locul de producere să fie în zonele unde existau bunuri alimentare.

\footnotetext{
${ }^{93}$ Scorpan 1975. 358.

94 Foarte importante sunt analizele lizico-chimice şi petrologice

${ }^{95}$ Rădulescu 1976
} 
Autorul împarte amforele în unsprezece mari categorii, dintre care şapte sunt romane târzii, stabileşte subtipuri, precizează locurile de descoperire şi datările acestora. Concluzia sa este că perioada dintre secolele al IV-lea şi al VII-lea p. Chr. se caracterizează printr-o producţie abundentă de amfore, cu numeroase variante, care au forme adecvate pentru cele mai diverse utilităţi, chiar dacă sunt lucrate mai grosolan ${ }^{96}$.

În anul 1976, C-tin Scorpan a publicat un articol în care încerca să răspundă la unele întrebări legate de originile şi liniile evolutive ale ceramicii romane târzii produsă în spaţiul mediteraneano-pontic ${ }^{97}$. Ca și în studiul precedent ${ }^{98}$, subliniază lipsa lucrărilor de sinteză, însă aminteşte contribuţiile lui D. Tudor ${ }^{99}$, I. Barnea ${ }^{100}$ şi A. Rădulescu ${ }^{101}$. Comparativ cu articolul din 1975, apar completări şi chiar modificări datorate volumului mare de material ceramic studiat. Astfel, anforele sunt împărțite în 24 de tipuri, dintre care peste $80 \%$ sunt produse în provinciile romane orientale $^{102}$, ulcioarele sunt împărțite în şase tipuri, iar oalele şi cănile — care formează ultima grupă- sunt de opt tipuri ${ }^{103}$. Deşi autorul însuşi recunoaşte că multe dintre concluziile şi graficele sale au un caracter relativ şi că aparifia altor descoperiri, clasificări şi interpretări pot aduce mici schimbări, teoriile despre circulaţia ceramicii pot răınâne valabile.

Alte trei articole dedicate materialului arheologic descoperit la Edificiul cu mozaic au apărut în anul 1976. În primul, M. Munteanu şi Gh. Papuc prezintă douăzeci de fragmente ceramice romano-bizantine cu decor ştampilat descoperite în campaniile din anii 1974-1975, într-un context stratigrafic databil între secolele al V-lea şi al VI-lea p. Chr. ${ }^{104}$ Ceramica cu decor ştampilat din Scythia Minor este caracteristică zonei orien-

\footnotetext{
" Rădulescu 1976. 111

${ }^{97}$ Scorpan 1976.

"Scorpan 1975.

9) Tudor 1941: Tudor 1941: Tudor 1953: Tudor 1968.

${ }^{100}$ Barneal 1966

${ }^{10 \mid}$ Rãdulescu $[972$ (mss).

102 Hăryile pe care sunt marcate punctele in care au fost descoperite amfore. pentru ctape cronologice şi tipuri diferite. pot ajuta la stabilirea zonelor de origine și a drumurilor de difuzare (Scorpan 1976, 168).

103. Scorpan 1976. 174

10.1 Muntcanu, Papuc 1976.
}

tale a Imperiului Roman ${ }^{105}$, sfera de interes economic şi cultural din care făcea parte acest teritoriu $^{106}$, dar există şi ceramică de provenienţă nordafricană $^{107}$.

Al doilea articol ${ }^{108}$, semnat de Gh. Papuc, este consacrat unui lot de 14 opaiţe de import ${ }^{109}$, cu decor în relief, descoperite la Tomis ${ }^{110}$. Datorită elementelor comune pe care le au aceste opaiţe şi ceramica cu decor ștampilat, piesele sunt datate in primele opt decenii ale secolului al V-lea p. Chr. ${ }^{111}$

C. Iconomu este autorul ultimului articol din seria celor trei amintite, iar materialul prezentat este format din cinci tipare de opaiţe ${ }^{1 / 2}$. Acestea se individualizează faţă de cele clasice prin formă, ornamentaţie, calitatea pastei şi a execuţiei şi sunt datate în secolele V-VI p. Chr. ${ }^{113}$ Opaiţe asemănătoare au fost descoperite la Dinogetia ${ }^{1 / 4}$, Sucidava ${ }^{115}$, Tomis și în alte locaţii ${ }^{116}$, în contexte arheologice din perioada amintită.

După anul 1970, fortificaţia de pe dealul Muzait $^{117}$, antica Sacidava, a fost subiectul multor studii în care este publicată multă ceramică romano-bizantină. Rezultatele cercetărilor arheologice, începute în anul 1969, au fost publicate de C-tin Scorpan, începând din anul $1972^{118}$ şi până în $1978^{119}$. În cele opt articole autorul abordează

\footnotetext{
${ }^{105}$ Hayes 1967, 323 şi urm.; Popescu 1965, 696-697: aptıd Munteanu, Papuc 1976, 148, nota 14

${ }^{106}$ Barnea 1968. 493.

107 Jodin. Ponsich 1960, 287-318: Jodin. Ponsich 1967. 449-544: apud Munteanu. Papuc 1976. 148. nota 16.

${ }^{108}$ Papuc 1976.

109 Aseınănătoare ca tehnică de lucru, pasıă. culoare si decor.

${ }^{110}$ Edificiul cu mozaic şi Piaţa Ovidiu.

111 Ccramica cu decor ştampilat a fost exportată şi în a doua jumătate a secolului al V-lea p. Chr. la Tomis

112 Patru jumătăł̧i cu care se confectiona partea superioară şi unul pentru partea inferioară, care nu face pereche cu nici unul din primele.

${ }^{113}$ Reprezintã varianta mai nouă a opaił̣elor care derivã din cele de tip nord-african datate între secolele al IV-lea şi al V-lea p. Chr.

${ }^{114}$ Barnea 1966, 243, lig. 5. 1-3; 257. fig. 14.6

115 Tudor 1968, 94-95, fig. 20/3-6: Tudor 1974, fig. 33/24.

116 Iconomu 1967, tipul XXX. 27, tipul XXXII, 28 (asemănător), nr. 725-726, $140 \quad$ (nr. 760, 762), 146 (asemănătoare).

117 Situată pe malul drept al Dunării şi teritoriul satului Dunăreni.

${ }^{118}$ Scorpan 1972; Scorpan 1972a.

119 Scorpan 1973a: Scorpan 1973b; Scorpan 1975: Scorpan
} 1976: Scorpan 1977a: Scorpan 1978. 
probleme diverse precum cea a continuităţii getodace, date generale în legătură cu perioada cuprinsă între secolele al VI-lea şi al VII-lea p. Chr. în Dobrogea, cercetările de la Sacidava şi ceramica descoperită în acest sit. Ca şi în articolul din anul 1975 ${ }^{120}$, C-tin Scorpan susţine, cu argumente solide, că la Sacidava existã două niveluri, sporadice e drept, post 614. Chiar dacă este un sit modest, Sacidava prezintă două mari avantaje: există o locuire romană continuă în perioada dintre secolul al II-lea şi începutul secolului al VII-lea p. Chr., când retragerea populaţiei s-a făcut treptat, iar situl nu este suprapus de o aşezare modernă şi poate oferi -în urma unor cercetări integrale - o imagine a locuirii romane pe cât posibil de completă.

Argumentele de mai sus vin să dea materialului ceramic de la Sacidava o mai mare importanţă în efortul de a înţelege unele aspecte legate de istoria sitului şi a limes-ului din perioada aflată în atenţia noastră. Într-un studiu'21 referitor la cercetările arheologice din anii 1977-1978 sunt publicate 37 de obiecte ceramice, inclusiv fragmente de tigle şi cărămizi ştampilate, 40 de obiecte metalice şi două obiecte din sticlă, majoritatea fiind importante pentru stratigrafia și cronologia sitului ${ }^{122}$. Cele şaptezeci şi nouă de obiecte reprezintă o mică parte a materialului arheologic descoperit, dar acoperă toată perioada de existentăa a celăł̧ii Sacidava ${ }^{123}$, iar autorul a considerat necesară cunoașterea, măcar parțială, până la publicarea monografici.

În articolul din $1977^{124}$, referitor la ceramica romano-bizantină din spaţiul istro-pontic, C-tin Scorpan „rupe” din cadrul mediteraneano-pontic aria istro-pontică dintre Dunăre, Balcani şi litoralıl Mării Negre şi stabileşte 23 de tipuri pentru amfore, şase pentru ulcioare şi opt pentru căni şi oale, la fel ca şi în articolul din anul 1976. Pentru amfore există opt hărţi în care sunt prezentate locurile de descoperire şi sunt propuse scenarii legate de zonele de origine şi difuziune a acestora. La final sunt câteva grafice care prezintă procentele ceramicii uzuale, amforelor importate

\footnotetext{
120 Scorpan 1975

121 Scorpan 1978

122 Scorpan 1978, 176

12.3 Secolele II-VII p. Chr

${ }^{124}$ Scorpan 1977
}

şi produselor locale databile între secolul al IV-lea şi secolul al VII-lea p. Chr., precum şi o diagramă care surprinde circulaţia ceramicii în spaţiul istropontic pentru aceeași perioadă. $\mathrm{Cu}$ foarte mici diferenţe, articolul este o reeditare, de data aceasta în limba franceză, a celui din anul 1976, în care C-tin Scorpan creionează originile şi liniile evolutive ale ceramicii romano-bizantine din spaţiul mediteranean şi pontic ${ }^{125}$

În anul 1979 a fost publicat primul volum dedicat sitului de la Tropaeum Traiani (Adamclisi, jud. Constanfa) ${ }^{126}$ care cuprinde şi un capitol dedicat ceramicii şi descoperirilor „mărunte”.

Ultimul studiu publicat în acest deceniu, referitor la ceramica romano-bizantină, este urmarea unei săpături de salvare care s-a desfăşurat vreme de două săptămâni în fortificaţia romanobizantină de la Babadag-Topraichioi (jud. Tulcea). În raportul prezentat la Oradea în anul 1979, A. Opait amintește descoperirea unor chiupuri şi prezintă patru vase ceramice ${ }^{127}$ datate la mijlocul secolului al V-lea p. Chr. ${ }^{128}$

Între anii 1980 şi 1989 va fi tipărit un număr aproximativ egal de articole, comparativ cu deceniul trecut, dar se manifestă, pentru prima dată, interesul arheologilor pentru aşezările rurale romane, în special cele aflate în teritoriul marilor aşezări antice. Chiar dacă erau documentate, prin periegheze sau descoperiri întâmplătoare, cercetările arheologice în teritoriile marilor oraşe pontice erau foarte rare până în anul 1980, astfel că informaţiile epigrafice nu puteau fi verificate în teren. Prima săpătură sistematică este cea efectuată de Al. Suceveanu în teritoriul anticei Histria, la Fântânele (jud. Constanţa) ${ }^{129}$. Din păcate stratul roman târziu, aflat la mică adâncime, a fost afectat de lucrările agricole ${ }^{130}$. Materialul ceramic descoperit în stratul romano-bizantin, aflat la $0,30-0,40 \mathrm{~m}$ adâncime, este format din amfore cu striuri drepte, cupe, boluri cu firnis şi alte tipuri

\footnotetext{
125 Scorpan 1976.

${ }^{126}$ Bogdan-Cătāniciu. Barnea 1979. 177-266.

${ }^{127}$ Trei amfore piriforme fragmentare și o farluric.

${ }^{128}$ Opail 1979

${ }^{129}$ Suceveanu 1979: Suceveanu 1981.

${ }^{130}$ Aceiaşi situaţie este întâlnită și la Histria ß (vezi Lungu. Bounegru, Avram 1984, 85-100).
} 
datate de autorul cercetării arheologice în secolele al IV-lea şi al V-lea p. Chr. ${ }^{131}$

Rezultatele celor şase campanii de săpături cfectuate la Gura Canliei ${ }^{132}$, între anii 1974-1976 şi 1978-1980, au fost publicate de M. Irimia în anul $1981^{133}$. Materialul ceramic descoperit este majoritar roman timpuriu, dar autorul cercetărilor spune că a surprins parţial şi câteva complexe arheologice romano-bizantine, cu material caracteristic: amfore „cu coaste” sau cu striuri dese şi uşor ondulate ${ }^{134}$. Din categoria ceramicii de bucătărie au fost descoperite fragmente de oale cu pasta roşcată cărăınizie sau cenuşie cărămizie, aspră şi cu nisip în compoziţie, cu buza —de obicei- evazată, uneori canelată, gâtul scurt şi torţile groase. Descoperirea unor tuburi de apeduct, cărămizi, olane şi ţigle arse intens, vitrifiate, constituie un argument pentru existenţa în zonă a unor instalaţii specializate în arderea materialelor de construcţie ${ }^{135}$. În cele şase campanii au fost cercetate câteva cuptoare, alte trei au fost identificate pe malul Dunării, dar nu au fost cercetate până în 1981 .

Alţi doi cercetători constănţeni, M. Bucovală şi Gh. Papuc, publicau în anul 1981 rezultatele campaniei din anul precedent ${ }^{136}$ efectuate în fortilicaţia de la Ovidiư ${ }^{137}$. După materialul arheologic descoperit ${ }^{138}$, se pare că fortificaţia ${ }^{139}$ a fost construită în secolul al IV-lea p. Chr. şi a funcţionat până în secolul al VI-lea sau chiar începutul secolului al VII-lea p. Chr. ${ }^{140}$ Chiar dacă a suferit o distrugere violentă în prima jumătate a secolului al VI-lea p. Chr, a continuat să fie locuită, însă funcţionalitatea defensivă a obiecti-

\footnotetext{
131 Suceveanu 1979.256.

1,2 Canlia. com. Lipnị̧a. jud. Constanta.

13.3 Irimia 1981.

134 Specifice sccolelor V-VI p. Chr.: vezi Rădulescu 1976 , 107-110, nr. 8, 10. pl. 8. 11: Scorpan 1976. 159, tip VII-A, pl. VII. XXXII, 163. เip VIII-B, pl. VIII, I-3 și XXXIII; Irimia 1968, 386-388 și fig. 13/1, 4-7. 9-10, 14.

1.35 Irimia 1981, 115.

136 Bucovală, Papuc 1981.

1.37 În coltul de sud-est al comunei, la $10 \mathrm{~km}$ nord de Constanţa. pe malul lacului Mamaia.

1 138 Monede. Cragmente de amfore târzii omamentate cu striuri orizontale ondulatc sau drepte, fragmente de farfurii sau platouri cu decor şlampilat, opaiţe.

${ }_{1.39}$ Un quadriburgium.

140 În secolul al VII-lea p. Chr. nu mai poate fi vorba de aspectul defensiv al fortificatiei. ci de o locuire care continuă între zidurile burgului.
}

vului fusese abandonată ${ }^{|4|}$. În acelaşi articol autorii spun că, în urma unor periegheze, au fost identificate alte şase puncte fortificate pe malul fostului golf al Mării Negre care au funcţionat şi în perioada romano-bizantină: Tomis ${ }^{142}$, Enisala $1^{143}$, Enisala $2^{144}$, Babadag-Topraichioi ${ }^{145}$ şi Palazu Mare ${ }^{146}$.

Unul dintre loturile ceramice romanobizantine importante din Dobrogea este cel semnat de Al. Suceveanu ${ }^{147}$, care cuprinde materialul descoperit cu prilejul cercetărilor sistematice din anii 1969 şi 1970, în sectorul central al cetăţii, la Basilica Episcopală. Autorul prezintă separat ceramica din fiecare nivel existent în zonă, astfel că pot fi observate diferenţele tipologice şi cantitative existente între perioadele istorice surprinse acolo. Din cele 248 de fragmente ceramice, doar 77 provin din straturile mai timpurii $^{148}$, restul de 171 fiind datate în secolele al VI-lea şi al VII-lea p. Chr. ${ }^{149}$ Chiar dacă cele două secţiuni reprezintă doar aproximativ $5,5 \%$ din suprafaţa vizată atunci şi materialul este destul de fragmentar, acest lot ceramic este foarte important pentru că provine dintr-o zonă compactă, una dintre puţinele ,insule" păstrate la Histria ${ }^{150}$. Importanta studiului se datorează şi faptului că la Histria au fost identificate douã niveluri datate sigur în secolul al VI-lea p. Chr., iar cantitatea mare de material ceramic permite urmărirea evoluţiei tipologice a ceramicii romano-bizantine până la începutul secolului al VII-lea p. Chr.

141 Bucovală, Papuc 1981, 215; situaţie similară la Tropaeum Traiani (vezi Papuc 1977, 357-360).

142 Î́n zona cea mai sudică a lacului, în apropierea cişmelei, intre şoseaua care merge spre Mamaia şi lac, pe un promontoriu. Autori susţin cã există mult material ceramic la suprafạă (Bucovală. Papuc 1981, 215).

${ }^{143}$ Pe malul lacului Babadag. la cca. $8 \mathrm{~km}$ de fortificatia de la Babadag, pe un promontoriu (Bucovală, Papuc 1981. 216).

${ }^{144}$ Sarichioi. jud. Tulcea. Pe malul lacului Babadag, la cca. $8 \mathrm{~km}$. de fortificaţia de la Babadag și la est de Enisala I (Bucovală. Papuc 1981, 216).

${ }^{145}$ La $2 \mathrm{~km}$ nord de Babadag. pe malul lacului cu acelaşi nume. pe un promontoriu (Opaiţ 1979; Bucovală, Papuc 1981. 216).

146 Jud. Constanţa, la $3 \mathrm{~km}$ sud-est de fortificaţia de la Ovidiu (Bucovală, Papuc 1981, 215).

${ }^{147}$ Suceveanu 1982.

${ }^{148}$ Secolele IV-V p. Chr.

${ }^{149}$ Repartizarea pe nivele este următoarea: II $\mathrm{B}=15$; III A $=22$; III $\mathrm{B}=14$; IV B $=82 ; \mathrm{V} \mathrm{A}=67 ; \mathrm{V} \mathrm{B}=22$.

${ }^{150}$ Suceveanu $1982,104$. 
Descoperirea ceramicii mai sus amintite aduce date noi în legătură $\mathrm{cu}$ schimbările pe care ceramica romană târzie le-a suferit intre secolele al IV-lea şi al VI-lea p. Chr. şi pe care majoritatea cunoscătorilor le vedeau în secolul al IV-lea $p$. Chr. La Hisiria schimbarea este surprinsă pe la mijlocul secolului al V-lea p. Chr., astfel că este foarte posibil ca modificările survenite să nu fie identificate corect pentru simplul motiv că nu existau incă loturi ceramice datate cert în acest secol. Ceramica de lux ${ }^{151}$ şi majoritatea amforelor, surprinse în toate nivelurile, erau importate din centre microasiatice sau constantinopolitane, având analogii perfecte ${ }^{152}$, dar nu sunt excluse nici cele africane. Ceramica de uz comun şi o parte din amfore au analogii la Tropaeum Traiani, dar nu şi la Iatrus, unde există material produs în atelierele nicopolitane ${ }^{153}$, motiv pentru care este considerată ca fiind produsă undeva în jurul unui mare oraş dobrogean ${ }^{154}$. Autorul nu exclude existenţa unei a treia grupe, cea locală, care poate cuprinde modele orientale, africane sau provinciale, produse la Histria, care poate fi dovedită prin cercetări interdisciplinare. Pentru a obţine informaţii cât mai apropiate de realitate, este necesară o corelare a informaţiilor arheologice cu cele oferite de epigrafie, numismatică sau demografie ${ }^{155}$.

Necropola romano-bizantină de la Callatis (Mangalia, jud. Constanţa) a beneficiat de o monografie publicată în anul 1980 și semnată de C-tin Preda ${ }^{156}$. În cazul acestui sit arheologic trebuie semnalat dezechilibrul dintre importanţa şi cantitatea mică de material ceramic publicat până în prezent. Deşi au trecut treizeci de ani de la apariţia lucrării lui C-tin Preda, aceasta rămâne singura dedicată ceramicii romane descoperită la Callatis. Singurii specialiști care au mai publicat ceramică descoperită la Callatis sunt A. Opaiţ, într-o lucrare dedicată producţiei ceramicii locale şi de import din Scythia Minor ${ }^{157}$ şi D. Paraschiv

\footnotetext{
151 Boluri, cupe, platouri.

152 Suciveanu 1982, 105.

15.3 Atelierele de la Butovo, Hotniţa şi Pavlikeni (Bulgaria) au asigurat. se pare. o unilormitate surprinzatoare a ceramicii din Mocsia Inferior (Suceveanu 1982. 105).

${ }^{154}$ Suceveanu 1982. 105.

155 Panclla $1983,61,62$

156 Preda 1980

${ }^{157}$ Opaį 1996, 112, PI. 45/1.2; I15-116. Pl. 46/4; 116-117.
}

într-o lucrare despre amforele romane şi romanobizantine în zona Dunării de Jos ${ }^{158}$. Adăugăm în această listă restrânsă lucrările publicate între anii 1967 şi 1976 de C. Iconomu ${ }^{159}$ despre opaiţele greco-romane existente în Muzeul de Istorie Naţională şi Arheologie din Constanţa, pe I. Barnea $^{160}$, precum şi două articole semnat de C-tin Scorpan care amintesc o amforă descoperită la Callatis $^{161}$.

În anul 1982, după săpăturile de la Fântânele ${ }^{162}$, trei arheologi din colectivul de la Histria ${ }^{163}$ au organizat periegheze în teritoriul cetăfii antice, prilej cu care au identificat aşezarea romană numită în literatura de specialitate Histria $\beta^{164}$. Cercetările făcute în anii 1982 şi 1983 au dus la concluzia că aşezarea a fost întemeiată în prima jumătate a secolului al II-lea p. Chr. Pe la jumătatea secolului al III-lea p. Chr. aşezarea a fost distrusă $^{165}$ şi, probabil, locuirea a fost reluată la sfârşitul aceluiași secol. Din păcate, stratul roman târziu $^{166}$, afectat de lucrările agricole, nu a putut fi surprins nici în plan şi nici în relief, situaţie întâlnită și la Fântânele. Totuşi, descoperirea a două monede (una de la Constanţiu II şi alta de la Constant, emisă între 341-346) poate fi un argument pentru locuirea aşezării în prima parte a secolului al IV-lea p. Chr. Chiar şi în aceste condiţii situl rămâne important pentru că, alături de cele de la Fântânele ${ }^{167}$ şi Sinoe-Vicus ${ }^{168}$, formează „clubul” select al aşezărilor rurale romane din teritoriul Histriei care au fost cercetate sistematic.

Pl. 47/6: 120-121. Pl. 50/13-15: 123-124. P1. 51/10.

${ }^{158}$ Paraschiv 2006. 86-87. 111 . nr. cat. 28. pl. 20/28.

159) Iconomu 1967: Iconomu 1976.

${ }^{160}$ Barnea 1968, 492, 542, liig. 53/3, 4 (un capac și un tipar de capac pentru vesela de bucālăric).

${ }^{161}$ Scorpan 1975. 275-276. Pl. IV/6: Scorpan 1976. PI. X/2. 162 Organizate de $\Lambda \mathrm{I}$. Suceveanu în anul 1978 (vezi Suceveanu 1979).

${ }^{16.3} \mathrm{~V}$. Lungu. O. Bounegru. Al. Avram.

${ }^{164} \mathrm{La} 1,5 \mathrm{~km}$ sud-sud-est de satul Istria si $200 \mathrm{~m}$ vest de lacul Istria, pe o pantă lină a unui deal: lungu. Bounegru. Avram 1984.

165 Ipoteza se bazează pe depistarea unui strat cu urme de arsură.

${ }^{166}$ Estc posibilă o locuire romanā doar în prima jumătate a sccolului al IV-lea p. Chr.

${ }^{167}$ Suceveanu 1979

${ }^{168}$ Canarache 1953 (rezultatele cercetării nu au fost deciât parţial publicate în acest articol). 
În acelaşi an a apărut un articol, semnat de N. Harţuche şi O. Bounegru, dedicat opaiţelor greceşti şi romane din colecţiile Muzeului Brăilei $^{169}$.

În anul următor (1983) au fost descoperite la Constanţa, în triunghiul format de bulevardele Republicii şi I Decembrie cu strada Basarabi, câteva morminte romane. În timpul săpăturii de salvare numărul lor a ajuns la 30 , dintre care 29 au fost datate larg în secolele II-IV p. Chr. şi unul singur in secolul al VI-lea p. Chr. ${ }^{170}$, toate fiind publicate de C. Chera-Mărgineanu şi $\mathrm{V}$. Lungu în anul $1984^{171}$. Inventarul ultimului mormânt, format dintr-o oală mare de bucătărie, fragmentară, cu caneluri pe corp şi toartă şi un opaiţ, ambele datate in secolul al Vl-lea p. Chr., era asociat cu o cataramă din fier care are — de obicei- o datare mai timpurie $^{172}$. Autorii articolului au gãsit analogii pentru vas ${ }^{173}$ în patru aşezări din Scythia Minor: Tomis $^{174}$, Dinogetia ${ }^{175}$, Sacidava ${ }^{176}$ şi Niculiţel ${ }^{177}$. Pentru opaị ${ }^{178}$ există analogii la Dinogetia ${ }^{179}$, Tropaeum Traiani $^{180}$, Callatis $^{181}$, dar şi la Athena ${ }^{182}$ sau în Pannonia ${ }^{183}$ şi Asia Micāō ${ }^{184}$.

La doi ani după perieghezele care au dus, între altele, la descoperirea aşezării rurale Histria B, câtiva arheologi ${ }^{185}$ din colectivul ,histrian"

\footnotetext{
1(19) Harluche. Bounegru 1982, 221-233.

${ }^{170}$ Mormântul 30

${ }^{171}$ Chera-Mārgincanu. Lungu 1984.

${ }^{172}$ Secolele IV-V p. Chr.

${ }^{173}$ Chera-Mārgineanu. Lungu 1984. M. 30. pl. VI, 52, 125.

${ }^{174}$ Chclută-Georgescu 1977, 254, pl. I/2 (complex funerar din secolul VI p. Chr.).

175 Barnea 1966. 255, lig. 14/1-2 (datată în secolul VI p. (hr.).

${ }^{176}$ Scorpan 1975, 308. PI. XIl, tip C. 9 (datată în secolul VI p. Chr.).
}

177 Baumann 1977, 256, pl. 1. 2 (datată în secolele V-VI p. Chr.: găsită în subsolul basilicii paleocreștine de la Niculipel).

${ }^{178}$ Chera-Mărgincanu, Lungu 1984, M. 30, pl. VI, 51, 125.

${ }^{179}$ Barnea 1966. 243. lig. 5/1-3 (datat în secolul al VI-lea p. (hr.).

${ }^{800}$ Barnea ef alii 1979. 222. fig. 173 (nivel VI B. datal în secolul al VI-lea p. Chr.).

${ }_{181}$ Necropola târzie. vezi Preda 1980. 181. pl. LI. M 9/2 (datat în secolul al VI-lea p. Chr.).

${ }^{182}$ Perlzweig 1961. pl. 96. nr. 2927 (datal în secolul al VIlà p. Chr.): apud Chera-Mărgineanu, Lungu 1984, 116. nota 38

18. Ivanyi, tip XIII. pl. XLV, 5: apud Chera-Mărgineanu. l.ungu 1984. 116. nota 39 .

${ }^{18.1}$ Menzel 1954. 98, pl. 80/2 (datat în sec. VI p. Chr.): apud Chera-Mărgineanu. Lungu 1984, 116. nota 37.

${ }^{185}$ Al. Avram. O. Bounegru, C. Chiriac. identificau alte trei aşezări rurale romane târzii. Prima este situată la $1 \mathrm{~km}$ nord de băile Nuntaşi, acolo unde a fost descoperită o mare cantitate de cărămizi pe o suprafaţă redusă, ceea ce indică urme de construcţii. La aproximativ $500 \mathrm{~m}$ distanţă au fost descoperite numeroase fragmente ceramice din epocă romană târzie ${ }^{186}$. A doua aşezare, numită de autori Nuntaşi Băi III ${ }^{187}$, se află la $300 \mathrm{~m}$ est-sud-est faţă de intersecţia cu şoseaua Năvodari-Mihai Viteazu ${ }^{188}$, iar ultima

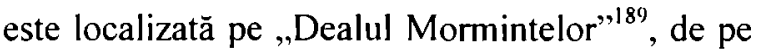
raza comunei Mihai Viteazu. Materialul ceramic recoltat în cele trei puncte, datat în secolele IV-VI p. Chr., este păstrat în depozitele şantierului Histria.

Acelaşi grup de arheologi, cărora li s-a alăturat E. Alexandrescu, au publicat în anul 1986 al treilea articol ${ }^{190}$ dedicat cercetărilor perieghetice din teritoriul cetății Histria. Numai unul dintre punctele identificate atunci ${ }^{191}$, situat pe malul stâng al Casimcei, în punctul numit „La pământul galben"'192, se încadrează, prin materialul ceramic descoperit, în perioada romană târzie. Materialul arheologic este, ca şi în cazul celorlalte periegheze, depozitat la Histria.

Într-un articol apărut în anul 1987, A. Opaiţ ${ }^{193}$ prezintă 20 de amfore romane de mare capacitate pe care le împarte în patru tipuri ${ }^{194}$, trei dintre acestea ${ }^{195}$ fiind produse până în perioada romană târzie ${ }^{196}$. Tipul II are o variantă ${ }^{197}$, databilă între jumătatea secolului al IV-lea şi secolul al VI-lea p. Chr., care este documentată la Sacidava $^{198}$, Dinogetia ${ }^{199}$, Tropaeum Traiani ${ }^{200}$,

\footnotetext{
186 La capătul de est al satului.

${ }^{187}$ Avram. Bounegru, Chiriac 1985, 123.

188 Pe malul nordic al pârâului Duingi Dere, în dreptul podului peste care trece şoseaua amintită.

189 În apropierca unei concentraţii de tumuli.

${ }^{90}$ Alexandrescu et alii 1986.

${ }^{191}$ Palazu Mic.

${ }^{192} \mathrm{La}$ l km nord-vest faţă de podul şoselei naţionale Constanła-Tulcea care iraversează Casimcea

${ }^{193}$ Opait 1987.

194 Toate au intre 4 şi 7 variante.

195 Tipurile II-IV.

$196 \mathrm{Au}$ fost descoperite în multe puncte de pe teritoriul dobrogean.

197 Varianta 7

${ }^{198}$ Scorpan 1973b, 288, fig. 36/4.

${ }^{199}$ Barnea 1966, 244, 257, fig. 8/6, 13/1 și 15/6-7.

${ }^{200}$ Barnea et alii 1979. 190, fig. 168/3.7.
} 

Histria $^{201}$,
Babadag-Topraichioi
Independența
(Murighiol) $^{203}$. Al existent încă din perioada elenistică, are cea mai târzie variantă descoperită la BabadagTopraichioi, datată în al doilea sfert al secolului al V-lea p. Chr. Ultimul tip are o variantă, descoperită la Independenţa (Murighiol) ${ }^{204}$, datată in secolul al IV-lea p. Chr., dar există o altă variantă descoperită la Roma într-un nivel din al doilea sfert al secolului al V-lea $\mathrm{p}$. Chr. ${ }^{205}$

După săpăturile arheologice din aşezarea Histria $\beta^{206}$, care au avut rolul de a aduce noutăți din punct de vedere stratigrafic şi cronologic în teritoriul Histriei, a urmat cercetarea celor două aşezări romane de la Cogealac ${ }^{207}$, efectuată în perioada 1984-1988. Așezarea din punctul numit „Bent” a avut două momente de locuire între a doua jumătate a secolului al II-lea şi începutul secolului al IV-lea p. Chr. Nu a fost surprins în săpătură un strat de arsură sau cenuşă, motiv pentru care distrugerea violentă a aşezării nu este un scenariu posibil ${ }^{208}$. Existența în zonă a unui apeduct care alimenta Histria, precum şi descoperirea mai multor monede din secolul al IV-lea p. Chr., au impus efectuarea unor săpături sistematice şi în aşezarea din punctul „Via lui Ciurea"209, rezultatele fiind prezentate în acelaşi articol semnat de V. Lungu, O. Bounegru şi Al. Avram. Materialele arheologice descoperite au dus la concluzia că în acest punct a existat o aşezare romană târzie, datată în prima jumătate a secolului al IV-lea, cu un singur nivel de locuire. Cum nici aici nu sunt urme de distrugere violentă, cste clar că nu toate aşezările rurale au fost afectate de invaziile din secolul al III-lea p. Chr. şi că unele au continuat să existe până în prima jumătate a secolului al IV-lea $p$. Chr.

\footnotetext{
${ }^{201}$ Amfora este cxpusă in Muzeul cetăţii Histria, nr. inv. V35141, dar nu sunt cunoscule condiţiile de descoperire.

202 Opait 1991 a.

${ }^{203}$ Opail 1991

${ }^{204}$ Coleçlia Muzeului Deltei Dunării, nr. inv. 40244 (apud Opai\} 1987, 253, nota 45).

${ }_{20}$ Opait 1987. 253. nota 46 şi fig. 7/1.

${ }^{206}$ Anii 1982-1983

207 L ungu, Bounceru, Avram 1990; jud. Constanţa

${ }^{208}$ Cum este cazul aşezārii din punctul Histria B.

204 La $1.5 \mathrm{~km}$ sud-est de comuna Cogealac, pe un platou înalt tăiat de pârâul Cogealac.
}

Foarte importante sunt şi rezultatele cercetărilor efectuate în fortificaţiile şi aşezările de la Babadag-Topraichioi şi Independenţa (Murighiol) publicate în anul 1991. Primul studiu $^{210}$, referitor la Babadag-Topraichioi, este semnat de A. Opaiţ, M. Zahariade, Gh. PoenaruBordea şi C. Opait. Au fost surprinse cinci niveluri arheologice incluse în două faze de locuire datate între deceniul şapte al secolului al IV-lea şi mijlocul secolului al V-lea p. Chr. Materialul ceramic prezentat în acest studiu, format din 235 de vase şi 30 de opaiţe, este impărţit după funcționalitate în patru mari grupe: vase de transport şi depozitare, de masă, de bucătărie şi de uz variat. Lotul folosit pentru statistici, mult mai numeros decât cel prezentat în catalog şi cel desenat, este prezentat în cele şapte tabele şi şapte diagrame şi este împărţit după criterii ca: nivelul şi sectorul de descoperire, centrul de producţie și categoria, tipul sau varianta ceramică în care se încadrează. Chiar dacă nu pot fi definitive, statisticile bazate pe stratigrafie şi tipologie oferă informaţii legate de raportul dintre producţia locală sau provincială şi importurile unui tip ceramic într-o anumită epocă istorică.

Pentru ceramica de la Independenţa (Murighiol) $^{211}$, A. Opait a optat pentru o prezentare tipologică şi selectivă $\breve{a l 2}^{21}$. Decizia sa este motivată de faptul că materialul ceramic roman târziu descoperit la Murighiol este mult mai bine reprezentat în comparaţie cu perioadele anterioare, fiind de peste 1200 de vase şi fragmente. Catalogul cuprinde 325 de vase, aproximativ un sfert din cantitatea totală, însă tot materialul a fost inclus în studiile statistice. Pentru a evidenţia fluctuaţiile cantitative între anumite categorii şi tipuri ceramice, în funcţie de nivelul de descoperire, autorul prezintă trei grafice şi opt tabele, în cele din urmă fiind folosit şi criteriul centrelor de producţie. Datorită descoperirilor numismatice modeste, autorul stabileşte doar o cronologie relativă pentru cele opt niveluri romane târzii şi crede că o datare absolută va fi posibilă după alte câteva campanii de cercetări arheologice.

\footnotetext{
${ }^{210}$ Opait 1991a.

211 Opait 1991.

${ }^{212}$ Opaiţ 1991. 167.
} 
În anul 1993 M. Bucovală publica un articol $^{213}$ în care prezenta două construcţii funerare $^{214}$ descoperite cu cinci ani mai devreme în curtea interioară a complexului comercial Egreta $^{215}$ din Constanţa. Într-unul dintre ele au fosı descoperite trei opaiţe întregi şi unul fragmentar datate în secolul al VI-lea şi începutul secolului al VII-lea p. Chr. ${ }^{216}$, două dintre ele având analogii în lucrarea lui C. Iconomu dedicatã opaiţelor greco-romane $e^{217}$.

În timpul unor lucrări industriale, demarate în anul 1987, au fost descoperite în fostul teritoriu al anticului Carsium două necropole romane. În vara aceluiaşi an, şase arheologi $i^{218}$, de la Muzeul Naţional de Istorie a României, au organizat săpături de salvare în timpul cărora au fost descoperite aproximativ 45 de morminte în prima necropolă. Pe baza unui inventar foarte sărăcăcios ${ }^{219}$, publicat într-un raport preliminar ${ }^{220}$ şi în cadrul unor manifestări locale din anii 19881989, necropola este datată între secolele al II-lea şi al VI-lea p. Chr. A doua necropolă romană de la Carsium, a fost cercetată ${ }^{221}$ de arheologii de la Muzeul de Istorie Naţională şi Arheologie din Constanţa $^{222}$. Materialul arheologic ${ }^{223}$ este datat între secolul I p. Chr. şi al VI-lea p. Chr. ${ }^{22-1}$ În anul 1993, într-un articol despre topografia Carsitum-ului $^{225}$, C-tin Nicolac aminteşte săpăturile de salvare din cele două necropole şi foloseşte rezultatele acestora pentru datarea fortificaţici. Autorul datează, „după ceramică”, prima fază a zidului de incintă, care uneşte fortificaţiile de pe Dealul „Cetăţii” şi Dealul

\footnotetext{
213 Bucovalā 1993.

214 Starea de conservare era proastã pentru că au fosı profanate în antichitate.

215 Complex allat la capătul dinspre gară al străzii Traian.

216 Bucovalā 1993. 212.

217 Opaifele cu numerele de inventar 37584 şi 37585 (vezi Iconomu 1967, 27. tip XXX. lig. 53-56. 137-138. 1ig. 160. nola 714

218 D. Popovici. L. Bătrâna. A. Bătrâna. C. Buzdugan. E. Oberländer-Târnoveanu. Al. Bolomey.

219) Un ulcior și câteva mãrgele.

220 Prezentat la Sesiunea anuală natională de la Sibiu, în anul 1988.

$2 \geq 1$ in anii 1987.1988.

222 P. I laşotti. A. Murat, Tr. Cliante şi G. Custurea.

223 Opaile. legule, monede, catarame (dintre care una datata in secolele V-VI p. (hr.).

$22-1$ Bounegeru. I Jaşotti. Murat 1989. 280 şi urm.

225 Nicolae 1993.
}

„Belciug”, în secolul al IV-lea p. Chr. A doua fază a zidului amintit este datată în secolul al VIlea p. Chr. pentru că a înglobat una din necropolele romane, intra muros". În acelaşi articol, C-tin Nicolae spune că în timpul săpăturilor de salvare din anii 1987-1988 a fost descoperită ${ }^{226}$ ceramică getică de epocă romană şi un fragment de vas cu monogramă creștină $\bar{a}^{227}$.

În anul 1995 a fost publicată o lucrare dedicată aşezărilor rurale antice din zona gurilor Dunării din perioada cuprinsă între secolul I p. Chr. şi secolul al IV-lea p. Chr. ${ }^{228}$ semnată de V.H. Baumann. Într-unul din cele cinci capitole este prezentată aşezarea de la Teliţa-Amza ${ }^{229}$ care, ca şi în epocile anterioare celei care ne interesează în studiul de fată, a fost locuită în perioada romană de o populaf̧ie getică şi a cunoscut extinderea maximă în secolul al IV-lea p. Chr. când ocupa o suprafată de 42 de hectare. În comparaţie cu celelalte două obiective care se încadrează în perioada vizată —aşezarea de la Sarichioi, punctul „Sărătura” şi ferma de la TeliţaValea Morilor - aşezarea de la Teliţa-Amza are analogii perfecte cu prima amintită precum și cu cea de la Frecăţei $i^{230}$. Autorul prezintă cataloage selective care cuprind 334 de obiecte descoperite în campaniile din anii 1987-1988, dintre care mai mult de jumătate reprezintă ceramică de perioadă romană. Din cele 178 de fragmente ceramice aproximativ $1 / 3$ sunt datate în secolele al III-lea şi al IV-lea p. Chr. sau chiar II-IV p. Chr., foarte larg din păcate, motiv pentru care trebuie să fie în atenţia noastră măcar în eventualitatea unei discuţii despre formele ceramice romane descoperite în aşezările rurale din Dobrogea între secolele al IV-lea şi al VI-lea p. Chr. Sunt de reţinut şi cele două ,,magazii" de chiupuri, în care au fost descoperite şapte asemenea vase, datate cu monede de la Diocleţian (295-298) şi Constanţiu II (355-361), care aparţin ultimei faze de locuire de la Teliţa-Amza. Catalogul selectiv cuprinde 115 fragmente ceramice, majoritatea databile în secolele al II-lea şi al III-lea p. Chr., dar între acestea există şi cinci datate de autor în ultimul

\footnotetext{
220 Pe strada Vadului. în gropi menajere.

227 Bounegru. Haşotti. Murat 1989, 280 şi urm.

228 Baumann 1995.

229 Jud. Tulcea.

${ }^{230}$ Baumann 1991a.
} 
veac de locuire. Cu siguranță că puţinătatea materialului ceramic roman târziu se datorează lucrărilor din perioada interbelică prin care s-a urmărit distrugerea „organizată a stratului arheologic superior" ${ }^{233}$.

$\mathrm{Cu}$ prilejul cercetărilor arheologice din anul 1982 au fost descoperite pe Valea Teliţei patru obiective din epocă romană, între care două ferme aflate la $2,5 \mathrm{~km}$ distanţă între ele. Materialul ceramic descoperit la ferma romană din punctul ,Hogea”, publicat de V.H. Baumann, provine din ccle două niveluri de locuire ale aceluiaşi strat de cultură şi se încadrează în formele frecvente din secolul al IV-lea p. Chr. În perimetrul amintit, unde au fost cercetate şi patru cuptoare, a fost descoperită o cantitate importantă de ceramică din care autorul a publical 23 de obiecte: amfore, boluri, oale-borcan, căni, suporţi şi capace, aproape trei sferturi find întregi sau întregibile ${ }^{232}$. În următorul capitol al aceleiaşi lucrări este publicată ceramica recoltată din umplutura cuptoarelor şi din gropile aferente acestora ${ }^{233}$. Lotul publicat cuprinde 190 de piese şi este foarte variat, demonstrând diversitatea tipurilor de vase fabricate aici în secolul al IV-lea p. Chr. ${ }^{234} \mathrm{La}$ finalul studiului autorul imparte ceramica în zece categorii ${ }^{23.5}$, prezentând numeric şi procentual repartizarea materialului într-un tabel şi o diagramă.

Articolelor semnate de Em. Popescu ${ }^{236}$ și Gh. Papuc ${ }^{237}$, dedicate ceramicii cu decor ştampilat de la Histria şi Tomis, li s-a adăugat o lucrare semnată Em. Popescu ${ }^{2.38}$, in care un studiu este dedicat antichităb̧ilor paleocreştine descoperite la Histria.

În anul 1996 contribuţiile lui FI. Topoleanu, prima în care sunt prezentate 35 de farfurii, fragmentare sau întregi, descoperite la

\footnotetext{
231 Baumann 1995. 174.

232 Batumann 1995, 268-397.

233 Baumann 1995. 398-437.

23 Studiul a lost prezentat in anul 1994 la al XIX-lca Congres Internalional Rei Cretariac Romanac Fautores de la Timişoara și a apărut în volumul Éudes sur la céramique romaine el daco-romaine de la Dacie et de la Mésie Inlérieure, Timişoara, 1997, 31-53+14 pl.

2,35 Oale. oale borcan. oale cu douá toarte. strachine. castroane. capace. cannile. ulcioare. amfore. opaiţe și suporţi. 236 Popescu 1965

237 Papuc 1973

2.38 Popescu 1994
}

Halmyris ${ }^{2.39}$, precum și una despre centrul de producţie a opaiţelor din acelaşi $\operatorname{sit}^{240}$. Materialul ceramic, împărţit după decor în 4 tipuri cu 15 modele diferite, este inclus într-un tabel statistic în care criteriile de clasare sunt: nivelul arheologic în care a fost descoperit, datarea, starea de conservare, compoziţia pastei, decorul şi centrele de producţie. Cele 35 de farfurii datează din perioada cuprinsă între secolul al V-lea şi începutul secolului al VII-lea p. Chr. şi au analogii în zona orientală a imperiului şi nordul Africii.

În același an a fost publicat un articol semnat de V. Georgescu și $M$. Ionescu ${ }^{241}$, dedicat mormintelor creştine descoperite în necropola romano-bizantină de la Callatis. Autorii sunt interesaţi de monumentele, elementele arhitectonice şi obiectele cu caracter creştin, motiv pentru care nu amintesc decât obiectele ceramice care au reprezentări sau înscrisuri specifice ${ }^{242}$. Printre altele este prezentat şi un opaiţ, descoperit în mormântul numărul 5, care este decorat pe toartă cu o cruce şi are analogii la Capidava ${ }^{243}$.

Fl. Topoleanu revine în anul $1999^{244} \mathrm{cu}$ un raport despre rezultatele cercetărilor arheologice din zona basilicii trinavate de la Argamum, în care este documentată o locuire romană târzie în secolele al V-lea şi al VI-lea p. Chr., eventual chiar începutul secolului uımător. În două dintre cele 18 fotografii prezcntate apar câteva chiupuri descoperite în anii 1991 şi 1992 care sunt datate la începutul secolului al VII-lea p. Chr., în ultimul nivel de locuire al sitului, atunci când sistemul defensiv al fortificaţiei lusese dezafectat.

În anul 2000 apărea la Tulcea o lucrare ${ }^{245}$ semnată de acelaşi Fl. Topoleanu, în care ceramica este ,.exploatată" sistematic iar concluziile sunt pe măsura efortului depus. Lucrarea este foarte bine organizată, unitară, riguroasă şi clară, oferind specialiştilor un instrument de lucru care mai umple câteva goluri referitoare la antichitatea Dobrogei şi nu numai. Foarte utile sunt graficele

\footnotetext{
239 Topoleanu 1996

240 . Topoleanu 1996a.

241 Georgescu. Ionescu 1996.

242 Capace, opaite.

243 Covacef, Corbu 1991, 289, lig. 1, 8. 9.

244 Topoleanu 1999.

245 Topoleanu 2000.
} 
care prezintă procentual repartiţiile în funcţie de categoria ceramică, starea de conservare, zona de producţie (pe niveluri sau în general) şi perioada de fabricare. Acestea sunt dublate de tabele, mult mai detaliate, care oferă statistici legate de repartiţia pe niveluri, starea de conservare, zona şi centrele de producție a ceramicii romane şi romano-bizantine descoperite la Halmyris. Din cele 2106 de fragmente ceramice sau vase ceramice prezentate în lucrare, 2040 provin de pe nivelurile romane târzii. Este adevărat că acest fapt se datorează sistemului de cercetare utilizat la Halmyris care a permis doar în primele campanii cercetarea parţială a nivelurilor timpurii ${ }^{246}$. Condiţiile care au dus numai la investigarea straturilor romane târzii nu sunt de discutat aici şi acum, important este că aproape $97 \%$ din materialul ceramic publicat de FI. Topoleanu este datat între secolele al IV-lea şi al VII-lea p. Chr. şi că acesta formează cel mai important lot ceramic publicat în România.

În acelaşi an, 2000, Fl. Topoleanu publica încă două articole: unul referitor la ceramica romană şi romano-bizantină locală sau importată la Malmyris din nordul Africii ${ }^{247}$. Acestui articol i se adaugă unul referitor la formele Hayes 3 şi Hayes 10 și un studiu despre ceramica descoperită la Halmyriss, în monografia dedicată acestui sit $^{2+8}$.

Se cuvine a aminti aici contribuţia foarte importantă a lui D. Paraschiv care a publicat, între anii 2000 şi 2006, sase articole referitoare la amforcle romano-bizantine care au circulat la Dunărea de $\operatorname{Jos}^{2 \cdot 19}$, la care se adaugă un alt articol scmnat de acelaşi autor împreună cu C-tin Băjcnaru" ${ }^{250}$. Într-unul din articole ${ }^{251}$, autorul prezintă punctul lui de vedere în legătură cu originea, răspândirea şi datarea unor amfore conice romano-bizantine, incluse de specialiști în mai multe tipuri şi forme ${ }^{252}$. D. Paraschiv împarte

\footnotetext{
$2+6$ Topoleamu 2000, 253.

247 Topoleanu 2000a.

$2 \cdot 18$ Topoleanu 2003. 190-245.

2.1) Paraschiv 2001: Paraschiv 2002: Paraschiv 2002a: Paraschiv 2003: Paraschiv 2004: Paraschiv 2004a.

$2:$ Paraschiv. Băjenaru 2003.

25 Paraschiv 2001 .

252 \%eest (tip 100), Beltrán L loris (lorma 78). Rädulescu (tip 9). Scorpan (tip XVII-R). Opait (lip IX: I a, b. c. d). Böttger (lip 1. Corma 6 si tip 11l. forma 2). Kuzmanov. (tipurile $X$ si X1). Empereur-Picon. (tip "Selcucia 1"). Krapivina (tip 29).
}

recipientele, în funcţie de capacitate şi de micile variaţii ale formei, în patru variante ${ }^{253}$ şi constată diferenţe de datare între zonele occidentale ${ }^{254}$ şi cele orientale. Majoritatea amforelor prezentate -13 la număr- provin din niveluri datate în Dobrogea între sfârşitul secolului al IV-lea şi începutul secolului al VI-lea p. Chr., iar în zona nord-pontică sunt descoperite în contexte arheologice datate până în al treilea sfert al secolului al VI-lea p. Chr. ${ }^{255}$

Celor şase articole de mai sus li se adaugă un altul dedicat ceramicii romane descoperite la Argamum $^{256}$, în sectorul extra muros şi, cu siguranţă cea mai importantă contribuţie a sa de până acum, o lucrare în care tratează amforele romane şi romano-bizantine descoperite în zona Dunării de $\operatorname{Jos}^{257}$. Aceasta din urmă este, în opinia noastră, cea mai reuşită încercare de prezentare a unei categorii ceramic - amforele - care a fost publicatā în România.

O altă lucrare importantă, apărută în anul 2003, este semnată de I. C. Opriş ${ }^{258}$. Cea mai mare parte a pieselor prezentate au fost descoperite într-un complex închis, horreum-ul roman târziư ${ }^{259}$, datat între secolul al IV-lea şi ultima parte a secolului al VI-lea p. Chr. Departajarea vaselor este făcută după formă şi funcţionalitate, iar în cadrul fiecărui capitol se apelează şi la criteriul morfologic. În capitolul doi sunt prezentate formele ceramice intâlnite la Capidava: amfore, vase de bucātărie (oalele lucrate cu mâna şi la roată lentă merită o discuţie mai largă legală de posibila lor origine şi populaţia care le-a folosit), vase de servit, vase cu destinaţie funerară sau liturgică. Opaiţelor le-a fost rezervat un capitol separat, în această lucrare fiind prezentate 48 din cele aproximativ 200 descoperite la Capidava. Lucrarea este de importanţă maximă pentru cunoaşterea ceramicii

Sazanov (tipurile 12 si 14), Bjelajac (lip XIlI): vezi Paraschiv 2001. 459.

${ }^{25.3}$ Databile intre slârşitul secolului al IV-lea şi secolul al V-lea p. Chr.

254 Amforele sunt datate între secolele al III-lea şi al V-lea p. Chr.

${ }_{255}$ A. Sazanov, apud Paraschiv 2001, 459, nota 12.

${ }^{250}$ Paraschiv $2006 a$.

${ }^{257}$ Paraschiv 2006

${ }^{258}$ Opriş 2003.

${ }^{259}$ Numit și ..corpul de gardă“. 
romane târzii din zona limes-ului şi, în general, a activităţii economice din Scythia Minor şi imprejurimi, motiv pentru care va fí cu sigurantă folosită de arheologii care se ocupă de ceramica romană târzie din partea orientală a imperiului şi nu numai.

În anul 2003 M. Angelescu şi A. Bâltâc publică un studiu ${ }^{260}$ referitor la sondajul „, $\alpha "$ din sectorul central al cetăţii Histria ${ }^{261}$, în care prezintă, pe lângă ceramica greacă, 38 de fragmente ceramice romane dintre care 13 pot fi datate şi în secolul al IV-lea p. Chr. Nivelurile surprinse în săpătură sunt prezentate separat, iar ceramica de perioadă greacă şi romană este prezentată în două cataloage diferite ${ }^{262}$.

Un alt lot ceramic important, descoperit la Histria în timpul cercetărilor de la Basilica Episcopală, a fost publicat în anul 2007 într-o lucrare dedicată acestui monument ${ }^{203}$. Cele 116 fragmente ceramice au fost împărţite în şase categorii: veselă pentru servitul mesei (37); veselă pentru servitul lichidelor (3); veselă de bucătărie (20); amfore (27); capace de amforă (8) şi opaiţe (21).

Încercând o privire retrospectivă asupra studiilor dedicate ceramicii romane în general, şi în mod special celei romane târzii descoperită pe tcritoriul dobrogean, pot $\mathrm{fi}$ trase concluzii în legătură cu modul de publicare, cantitatea de ceramică descoperită sau importanł̧a pe care a căpătat-o aceasta în special în ultimele trei decenii.

În perioada interbelică au fost publicate doar câteva artefacte ceramice. fapt datorat în special lui V. Pârvan. Această perioadă de început pentru studierea ceramicii în România se caracterizează prin lipsa interesului pentru materialul ceramic care, dacă nu era reprezentat prin piese deosebite, nu reprezenta o prioritate.

De la sfârşitul deceniului cinci al secolului trecut şi până la începutul celui de-al şaptelea,

\footnotetext{
${ }^{200}$ Angelescu. Bâltâc 2003, 104-107.

201 Săpãturile de la Basilica Episcopală au început în anii 1969-1970 (vezi Suceveanu. Scorpan 1971) și au lost reluate în 1984 (Scopul principal era cercetarea acestui monument construit în prima jumătate a secolului al Vl-lea p. Chr.).

202 În total 179 de vase ceramice fragmentare sau întregi.

${ }^{20.3}$ Suceveanu 2007. 204-221. P1. 1-6.
}

ceramica era amintită rar în rapoartele de săpătură, iar atunci când existau asemenea informaţii se refereau la categorii ceramice mari sau piese speciale.

După anul 1960 au urmat trei decenii importante din acest punct de vedere pentru că au fost făcute multe cercetări şi o parte importantă din materialul descoperit a fost publicat. În perioada mai sus amintită multe dintre săpăturile arheologice efectuate au fost de salvare, urmare a descoperirilor întâmplătoare dintr-o perioadă în care se construia foarte mult în toată tara.

După 1990 ritmul de publicare a materialului ceramic roman a rămas important, însă schimbările pozitive sunt de remarcat în privinţa modalităţilor de publicare. Au fost publicate câteva loturi ceramice importante care au umplut mari goluri în acest domeniu şi au redus decalajele existente între zona geografică în care ne aflăm şi vestul Europei. Dacă ne raportăm la zona Dunării de Jos, numărul siturilor cercetate şi cantitatea de material ceramic publicat, situaţia Dobrogei nu este dramatică, însă decalajele dintre zonele mediteraneană şi pontică sunt multe, importante şi, din păcate, nu se datorează în totalitate motivelor financiare. Lipsa unei metodologii comune pe care să o folosească toţi cei implicaţi în acest proces minimalizează rezultatele obţinute. Suntem în faţa unui uriaș puzzle din care àvem doar câteva piese. Evident că o parte importantă a pieselor sunt pierdute definitiv și că imaginea nu va fi completă niciodată, însă unele pot fi recuperate de sub munţii de ceramică uitată prin depozitele muzeelor şi şantierelor arheologice. Altfel, vom fi condamnaţi la necunoaştere, la crâmpeie de informaţie care nu pot forma un ,întreg". 


\section{BIBLIOGRAFIE}

Alexandrescu et alii 1986 - E. Alexandrescu, Al. Avram, Oc. Bounegru, C. Chiriac, Cercetäri perieghetice în teritorizl Histrian (II), Pontica, XIX, 1986, p. 243-252.

Angelescu, Bâltâc 2003 - M. V. Angelescu, A. Bâltâc, Sondajul „a” din Basilica Episcopală de la Histria, Pontica, XXX-XXXVI, 2002-2003, p. 85-122.

Aricescu 1971 - A. Aricescu, Noi date despre cetatea de la Hârşova, Pontica, 4, 1971, p. 351-370.

Avram, Bounegru, Chiriac 1985 - Al. Avram, Oc. Bounegru, C. Chiriac, Cercetări perieghetice în teritoriul Histriei (I), Pontica, XVIII, 1985, p. 113-124.

Barbu 1971 - V. Barbu, Din necropolele Tomisului, StCerclstorV, 22, 1971, 1, p. 53-65.

Barnea 1958 - I. Bamea, Monumente de artă creștină descoperite pe teritoriul R.P.R., ST, 5-6, seria II-a, 1958, p. $287-310$.

Barnea 1966 - I. Barnea, L'incendie de la cité de Dinogetia au vt' siècle, Dacia N.S., X, 1966, p. 237-259.

Barnea 1968 - I. Bamea, Perioada Dominatului, în R. Vulpe, I. Barnea, Din istoria Dobrogei. Romanii la Dunărea de Jos, II, Bucureşti, 1968, p. 337-556.

Barnea 1969 - I. Bamea, O casă romană târzie de la Dinogetia, StCerclstorV, 20, 1969, 2, p. 255-265.

Barnea et alii 1979 - I. Barnea, Al. Barnea, I. Bogdan-Cătănciu, M. Mărgineanu-Cârstoiu, Gh. Papuc, Tropaeum Traiani, Cetatea, I, Bucureşti, 1979.

Baumann 1977 - V. H. Baumann, Câteva precizări rezultate din cercetarea monumentului paleocreştin din com. Niculijel (jud. Tulcea), ActaMusNapoca, 14, 1977, p. 245-267.

Baumann 1980 - V. H. Baumann, Cercetări arheologice din ferma romană de la Telita, MatCercA, XIV, Tulcea, 1980 , p. 304-313.

Baumann 1984 - V. H. Baumann, Raport cu privire la rezultatele cercetărilor arheologice de la Telifa „Izvorul Maicilor" jud. Tulcea, 1979, Peuce, IX, 1984, p. 41-50.

Baumann 1984a - V. H. Baumann, Raport asupra cercetărilor arheologice efectuate in ferma romană de la Telifa, punctul la "Pod" jud. Tulcea, in anul 1980. Peuce, IX, 1984, p. 51-65, 457-472.

Baumann 1991 - V. H. Baumann, Un nou cuptor de ars material tegular, descoperit in ferma romană târzie de la Telita, punctul ,, La Pod", jud. Tulcea, Peuce, X, 1991, I. p. 105-107; II. p. 103-110.

Baumann 1991a - V. H. Baumann, Cercetări arheologice pe valea Telifei (jud. Tulcea) I. Sondajul de la Frecătei, Peuce, X, 1991, p. 109-115.

Baumann 1991b - V. H. Baumann, Cercetări recente la bazilica paleocreștină din satul Niculițel (judełul Tulcea), Peuce, X, 199I, I. p. 121-125; II. p. 145-156.

Baumann 1995 - V. H. Baumann, Aşezări rurale antice in zona gurilor Dunării. Contributii arheologice la cunoaşterea habitatului rural (sec. $1-I V$ p. Chr.), Tulcea, 1995.

Baumann 1997 - V. H. Baumann, La ceramique utilitaire du $\|^{\prime \prime}$ siècle fabriqué par l'officina romana de Valea Morilor (Telita département de Tulcea), Études sur la céramique romaine et daco-romaine de la Dacie et de la Mésie Inférieure, Timişoara, 1997, p. 31-53+14 pl.

Bogdan-Cătăniciu, Barnea 1979 - I. Bogdan-Cătăniciu, I. Barnea, Ceramica şi descoperiri mărunte, în Barnea et alii 1979, p. 177-266.

Bouncgru, Haşotti, Murat 1989 - O. Bounegru, P. Haşotti, A. Murat, Aşezarea daco-romană de la Hârşova şi unele aspecte ale romanizării în Dobrogea, StCercIstorV, 1989, 3, p. 273-294.

Bouncgru 1989 - O. Bounegru, Contribufii privind răspândirea și cronologia ceramicii decorate in tehnica barbotinei din Dobrogea romană, Pontica, XXI-XXII, 1988-1989, p. 99-111.

Bouncgru 2001 - O. Bounegru, Date stratigrafice recente privind refeaua stradală din cartierul ", Domus" de la Histria, Pontica, XXXIII-XXXIV, 2000-2001, p. 397-413.

Bucovală 1984 - M. Bucovală, Date noi despre cercetările arheologice de la Ovidiu, Pontica, XVIII, 1984, p. $153-156$.

Bucovală 1993 - M. Bucovală, Covou din secolul IV d. Chr. descoperit in necropola de vest a Tomisului, Pontica, XXVI, 1993, p. 207-214.

Bucovală, Papuc 1981 - M. Bucovală, Gh. Papuc, Date noi despre fortificafia de la Ovidiu -municipiul Constanta (Campania 1980), Pontica, XIV, 1981, p. 211-216.

Bucovală, Pașca 1989 - M. Bucovală, C. Paşca, Descoperiri recente in necropolele de epocă romană și romanobizuntină la Tomis, Pontica, XXI-XXII, 1988-1989, p. 123-160.

Bucovală, Paşca 1991 - M. Bucovală, C. Paşca, Descoperiri recente in necropola romană de sud-vest a Tomisului, Pontica, XXIV. 1991, p. 185-236. 
Bujor 1958 - Ex. Bujor, Santierul arheologic Murighiol (r. Tulcea, reg. Constanta), MatCercA, V, 1958, p. 373378.

Bujor 1960 - Ex. Bujor, Santierul arheologic Murighiol (r. Tulcea, reg. Constanta), MatCercA, VII, 1960, p. 297-300.

Canarache 1953 - V. Canarache, Sinoe-Vicus, StCercIstorV, 4, 1953, 1-2, p. 136-138.

Cheluţă-Georgescu 1974 - N. Cheluţă-Georgescu, Complexe funerare din secolul VI e.n. la Tomis, Pontica, 7, 1974, p. 363-376.

Chera-Mărgineanu, Lungu 1984 - C. Chera-Mărgineanu, V. Lungu, Noi descoperiri din necropolele timitane, Pontica, XVII, 1984, p. 109-130.

Comşa M 1972 - M. Comşa, Elemente „, barbare” in zona Limes-ului Dunării inferioare în secolele al III-lea şi al IV-lea, Pontica, 5, 1972, p. 223-234.

Condurachi et alii 1959 - E. Condurachi, D. Pippidi, G. Bordenache, I. Stoian, S. Dimitriu, M. Coja, V. Eftimie, C. Radu, P. Alexandrescu, Em. Popescu, P. Aurelian, N. Hamparţumian, V. Zirra, Şantierul Histria, MatCercA, 6, 1959 , p. 266-306.

Condurachi et alii 1960 - E. Condurachi, D. Pippidi, G. Bordenache, Iorgu Stoian, S. Dimitriu, N. Coja, P. Alexandrescu, P. Aurelian, E. Popescu, V. Eftimie, N. Hamparţumian, C. Radu, Şantierul arheologic Histria, MatCercA, VII, 1960, p. 227-271.

Constantinescu 1967 - R. Constantinescu, Les martyrs de Durostorum, RÉSEE, 5/1-2, 1967, p. 5-20.

Covacef, Corbu 1991 - Z. Covaceff, E. Corbu, Consideratii asupra unei categorii de opaite descoperite in sectorul V al cerătii Capidava, Pontica, XXIV, 1991, p. 287-297.

Culică 1969 - V. Culică, Obiecte de caracter creştin din epoca romano-bizantină găsite la Pirjoaia-Dobrogea, Pontice, 2, 1969, p. 355-371.

Florescu 1955 - Gr. Florescu, Un tip ceramic necunoscut din veacul al VI-lea, SCIA, II, 3-4, 1955, p. 338-342.

Gcorgescu, Ionescu 1996 - V. Georgescu, M. Ionescu, Mărturii creştine la Callatis, Pontica, XXVIII-XXIX, 1995-1996, p. 187-200.

Harţuche, Bounegru 1982 - N. Harţuche, O. Bounegru, Opaife greceşti și romane din colecfiile Muzeului Bräilei, Pontica XV, 1982, p. 221-233.

Iconomu 1967 - C. Iconomu, Opaite greco-romane. Muzeul de Arheologie Constanta, Bucureşti, 1967.

Iconomu 1968 - C. Iconomu, Cercetări arheologice la Mangalia şi Neptun, Pontice, 1, 1968, p. 235-268.

Iconomu 1970 - C. Iconomu, Un depozit de lucerne la Constanta, Pontica, III, 1970, p. 237-253.

Iconomu 1976 - C. Iconomu, Descoperiri de tipare de opaite la Tomis, Pontica, IX, 1976, p. 135-146.

Irimia 1968 - M. Irimia, Cuptoarele romano-bizantine de ars ceramică de la Oltina (jud. Constanta), Pontice, 1, 1968 , p. $379-408$.

Irimia 1981 - M. Irimia, Observatii preliminare privind aşezarea antică de la Gura Canliei, Pontica, XIV, 1981, p. $67-122$.

Iványi 1935 - D. Iványi, Die pannonischen Lampen. Ein typologischchronologische Übersicht, Diss. Pann., 2, ser. 2, Budapesta, 1935.

Lambrino 1931 - Scarlat Lambrino, Empereur pré-byzantin figuré sur une coupe en terre-cuite, RIR, I, 1931, p. 63-74.

Lungu, Bounegru, Avram 1984 - V. Lungu, O. Bounegru, Al. Avram, Cercetările arheologice din aşezarea romană rurală de la Histria $\beta$, Pontica, XVII, 1984, p. 85-100.

Lungu, Bounegru, Avram 1990 - V. Lungu. O. Bounegru, Al. Avram, Cercetările arheologice din aşezările romane de la Cogelac, Pontica, XXIII, 1990, p. 161-175.

Menzel 1954 - H. Menzel, Antike Lampen im Römisch-Germanischen Zentralmuseum zu Mainz, Mainz, 1954.

Munteanu, Papuc 1976 - M. Munteanu, Gh. Papuc, La céramique romaine tardive à décor estampé découverte à Tomis, Pontica, IX, 1976, p. 147-154.

Muşcteanu 2003 - C. Muşețeanu, Ateliere ceramice romane de la Durostorum, Bucureşti, 2003.

Nicolac 1993 - C-lin Nicolac, Despre topografia anticului Carsium, Pontica. XXVI, 1993, p. 215-229.

Nubar 1971 - N. Hamparţumian, Contributii la topografia cetătii Histria in epoca romano-bizantină. Consideratii generale asupra necropolei din sectorul bazilicii „extra muros", StCercIstorV, 22, 1971, 2, p. 199 215 .

Opaiţ, Sion, Vasiliu 1980 - A. Opaiţ, A. Sion, I. Vasiliu, Aegyssus '79, Peuce, VIII, 1980, p. 267-275.

Opait, Zahariade 1980 - A. Opait, M. Zahariade, Cercetările arheologice de la fortificatia romano-bizantină de la Topraichioi-Babadag, Peuce, VIII, 1980, p. 335-341.

Opait, Opaiţ, Bănică 1990 - A. Opaiţ, C. Opaiţ, T. Bănică, Complexul monastic paleocreştin de la Slava Rusă, RMI, 59, 1, 1990, p. 18-28.

Opait 1977 - A. Opaił, Aegyssus '76. Raport preliminar, Pontica, X. 1977, p. 307-311.

Opait 1979 - A. Opaiț, O nowă fortificafie romano-bizantină in nordul Dobrogei - Topraichioi. Raport preliminar; MatCercA, XIII, Oradea, 1979, p. 325-331. 
Opaif 1980 - A. Opait, Consideratii preliminare asupra amforelor romane si romano-bizantine din Dobrogea. Consideratii preliminare asupra ceramicii romane de la Troesmis, Peuce, VIII, 1980, p. 291-327.

Opaif 1980a - A. Opaiţ, $O$ nouă fortificatie romano -bizantină în nordul Dobrogei. Topraichioi -Raport preliminar, Peuce, VIII, 1980, p. 415-449.

Opait 1984 - A. Opait, Beobachtungen zur Entwicklung der zwei Amphoratypen, Peuce, IX, 1984, p. 311-327.

Opaił 1985 - A. Opaiț, Einige Beobachtungen zur spätrömischen Keramik mit rotem Uberzug, Dacia N.S., XXIX, 1985, p. 153-163.

Opaif 1987 - A. Opaiţ, Amfore romane de mare capacitate. Considerații tipologice, StCerclstorV, 38, 1987, 3, p. 245-258.

Opait 1987a - A. Opaiţ, Un dépót d'anphores découvert à Aegyssus, Dacia N.S., 30, 1987, 1-2, p. 145-155.

Opait 1991 - A. Opaiţ, Ceramica din aşezarea și cetatea de la Independenta (Murighiol) in secolele V i.e.n.-VII e.n., Peuce, X, 1991, I. p. 133-182; II. p. 165-216.

Opait 1991a - A. Opaiţ, Ceramica, în A. Opaiţ, M. Zahariade, Gh. Poenaru-Bordea, C. Opaiţ, Fortificația şi aşezarea romană târzie de la Babadag-Topraichioi, V, Ceramica, Peuce, X, 1991, I. p. 21 l-269; II. p. 219-283.

Opaiţ 1991b - A. Opaiț, O săpătură de salvare in oraşul antic Libida, StCerclstorV, 42, 1991, 1-2, p. 21-56.

Opait $1991 \mathrm{c}$ - A. Opait, Elemente etnice nord-dunărene in Scythia Minor (secolele IV-V p. Chr.), Peuce, X, 1991 , p. $127-132$.

Opait 1996 - - A. Opait, Aspecte ale vietii economice din provincia Scythia (secolele IV-VI p. Chr.). Productia ceramicii locale și de import, Bucureşti, 1996.

Opait 1998 - A. Opaiţ, North African and Spanish Amphorae in Scythia Minor, Il Mar Nero, III, 1997-1998, p. 47-95.

Opait 1998a - A. Opait, New pottery from the circular harbour of Carthage, CEDAC Carthage Bulletin 18, 1998, p. $21-35$.

Opait 2000 - A. Opaith, Early Roman Amphorae from Leptiminus, ReiCretActa 36, Abingdon, 2000, p. 439-442.

Opait 2002 - A. Opait, The Eastem Amphorae in the Province of Scythia, în J. Eiring, J. Lund (eds.). Transport Amphorae and Trade in the Eastem Mediterranean. Acts of the International Colloquium at the Danish Institute ai Athens, September 26-29, 2002, Monographs of the Danish Institute at Athens 5, Athens, 2002, p. 293-308.

Opait 2004 - A. Opait, Local and imported ceramics in the Roman Province of Scythia $\left(4^{\text {th }}-6^{\text {th }}\right.$ centuries $\left.A D\right)$, Oxford, 2004.

Opriş 2003 - I. C. Opriş, Ceramica romană târzie şi paleobizantină de la Capidava în contextul descoperirilor de la Dunărea de Jos (sec. IV-VI p. Chr.), Bucureşti, 2003.

Papuc 1973 - Gh. Papuc, Ceramica romană târzie cu decor ștampilat descoperită la Edificiul roman cu mozaic din Tomis, Pontica, VI, 1973, p. 153-192.

Papuc 1976 - Gh. Papuc, Opaife de import la Tomis, Pontica, IX, 1976, p. 201-205.

Papuc 1977 - Gh. Papuc, Considerafii asupra perioadei de sfârşit a cetătii Tropaeum Traiani, Pontica, X, 1977, p. $357-360$.

Papuc, Munteanu 1976 - Gh. Papuc, M. Munteanu, La céramique romaine tardive à décor estampé découverte à Tomis, Pontica, IX, 1976, p. 147-154.

Paraschiv 1997 - D. Paraschiv, Descoperiri arheologice de epocă romană la Măcin, Pontica, XXX, 1997, p. $317-330$.

Paraschiv 2001 - D. Paraschiv, Observalii asupra unui tip de amfore romano-bizantine, Pontica, XXIII-XXXIV, 2000-2001, p. 459-468.

Paraschiv 2002 - D. Paraschiv, Amfore pontice la Dunărea de Jos, AMold, XXV, 2002, p. 165-207.

Paraschiv 2002a - D. Paraschiv, Amfore romano-bizantine descoperite la Piatra Frecălei-Beroe, Cercetări Istorice. Revista Muzeului de Istorie a Moldovei, laşi, S. N. 18-20, 1999-200 I (2002), p. 149-156.

Paraschiv 2003 - D. Paraschiv, Amfore occidentale romane in zona Dunării de Jos, Pontica, XXXV-XXXVI, 2002-2003, p. 177-207.

Paraschiv 2004 - D. Paraschiv. Noi descoperiri arheologice de epocă romană la Macin, Peuce S.N., 2, 2004, (15), p. 143-152.

Paraschiv 2004a - D. Paraschiv, Cercetările arheologice de la Baia (jud. Tulcea), punctul „Statia de epurare”, Peuce S.N. 2 (15), 2004, p. 153-158.

Paraschiv 2006 - D. Paraschiv, Amfore romane şi romano-bizantine în zona Dunării de Jos (sec. I-VII), Iaşi, 2006.

Paraschiv 2006a - D. Paraschiv, Contributii privind ceramica romană de la Argamum. Sectorul extra muros.I. Amforele, în Orgame/Argamum, Suplementa 1, A la recherché d'un colonie, Bucarest, 2006.

Paraschiv, Băjenaru 2003 - D. Paraschiv, C. Băjenaru, Două amfore italice romano-bizantine descoperite in Dobrogea, Peuce S. N. 1 (14), 2003, p. 233-236.

Pârvan 1914 - V. Pârvan, Cetatea Ulmetum, II, București, 1914.

Pârvan 1974 -- V. Pârvan, Inceputurile viefii romane la gurile Dunării, Bucureşti, 1974. 
Perlzweig 1961 - J. Perlzweig, The Athenian Agora, VII, Lamps of the Roman Period, Princeton, New Jersey, 1961.

Popescu 1965 - Em. Popescu, Ceramica romană târzie cu decor ştampilat descoperită la Histria, StCerclstorV, 16, 1965, 4, p. 695-724.

Popescu 1994 - Em. Popescu, Les antiquités paléochrétiennes d'Histria, Christianitas daco-romana. Florilegium studiorum, București, 1994, p. 306-396.

Preda 1980 - C-tin Preda, Callatis. Necropola romano-bizantină, Bucureşti, 1980.

Rădulescu 1966 - Al. Rădulescu, Monumente romano-bizantine din sectorul de vest al cetăfii Tomis, Constanţa, 1966.

Rădulescu 1969 - Al. Rădulescu, Ateliere meşteşugăreşti pentru ars materiale de construcfie din lut, Pontice, 2, 1969, p. 333-353.

Rădulescu 1972 (mss) - Al. Rădulescu, Meşteşugurile in Dobrogea romană, I, Ceramica, mss. 1972.

Rădulescu 1973 - Al. Rădulescu, Ateliere ceramice militare de-a lungul Dunării de Jos, Pontica, VI, 1973, p. $129-135$.

Rădulescu 1973a - Al. Rădulescu, Amfore cu inscriptii de la Edificiul roman cu mozaic din Tomis, Pontica, VI, 1973, p. 193-207.

Rădulescu 1975 - Al. Rădulescu, Contributii la cunoassterea ceramicii de uz comun din Dobrogea, Pontica, VII, 1975, p. 331-360.

Rădulescu 1976 - Al. Rădulescu, Amfore romane şi romano-bizantine din Schytia Minor, Pontica, IX, 1976, p. 99-114.

Rădulescu et alii 1973 - Al. Rădulescu, C-tin Scorpan, Gh. Papuc, E. Coman, C. Stavru, Recente cercetări arheologice la Tomis (I97I, 1972), Pontica, VI, 1973, p. 333-350.

Rădulescu, Scorpan 1975 - Al. Rădulescu, C-tin Scorpan, Rezultate preliminare ale săpăturilor arheologice din Tomis (Parcul Catedralei), 1971-1974, Pontica, VIII, 1975, p. 9-54.

Scorpan 1968 - C-tin Scorpan, Contribufii arheologice la problemele etnice ale Dobrogei antice. I. Carpii in Scythia Minor, Pontice, 1, 1968, p. 342-364.

Scorpan 1972 - C-tin Scorpan, Sacidava si unele probleme stratigrafice si cronologice ale Limes-ului şi Dobrogei romane (Secolul V in arheologia dobrogeană), Pontica, V, 1972, p. 301-327.

Scorpan 1972a - C-tin Scorpan, Date arheologice referitoare la sec. VI şi VII pe teritoriul Dobrogei (Rezultate inedite la Tropaeum și Sacidava), Pontica, V, 1972, p. 349-372.

Scorpan 1973 - C-tin Scorpan, La continuite de la population et des traditions getes dans les conditions de la romanisation de la Schytia Minor, Pontica, VI, 1973, p. 137-151.

Scorpan 1973a - C-tin Scorpan, Tipi sconosciuti di lumini a olio romani e il problema di certe trasmissioni nel primo feudalismo, Pontica, VI, 1973, p. 209-228.

Scorpan 1973b - C-tin Scorpan, Săpăturile arheologice de la Sacidava (1969, 1970, 197I), Pontica, VI, 1973, p. $267-331$.

Scorpan 1975 - C-tin Scorpan, Ceramica romano-bizantină de la Sacidava, Pontica, VIII, 1975, p. 263-313.

Scorpan 1976 - C-tin Scorpan, Origini și linii evolutive in ceramica romano-bizantină (sec. IV-VII) din spatiul mediteranean si pontic, Pontica, IX, 1976, p. 155-185.

Scorpan 1977 - C-tin Scorpan, Contribution à la connaissance de certains types céramiques romano-bizantins (IV'-l'll' siècles) dans l'espace istro-pontique, Dacia N.S., XXI, 1977, p. 269-297.

Scorpan 1977a - C-tin Scorpan, Rezultate ale săpăturilor arheologice de la Sacidava (1974-1976), Pontica, X, 1977, p. 229-251.

Scorpan 1978 - C-tin Scorpan, Descoperiri arheologice diverse la Sacidava, Pontica, XI, 1978, p. 155-180.

Suceveanu 1979 - Al. Suceveanu, Raport asupra cercetărilor de la Fântânele din anul 1978, MatCercA, XIII, Oradea, 1979 , p. 255-256.

Succveanu 1981 - Al. Suceveanu, Fondul getic autohton şi procesul romanizärii in Dobrogea secolelor I-III e.n. in lumina săpăturilor de la Straja și Fântânele, Thraco-Dacica, 2, 1981, p. 217-220.

Succveanu 1982 - Al. Suceveanu, Contributii la studiul ceramicii romano-bizantine de la Histria, StCerclstorV, $33,1,1982$, p. $79-107$.

Succveanu 2000 - Al. Suceveanu, Histria X. La céramique romaine des $f^{t r}-I I t t^{\prime}$ siècles ap. J.-C., Bucarest, 2000.

Sucevcanu 2007 - Al. Suceveanu, Histria XIII. La Basilique Épiscopale, Bucarest, 2007.

Sucevcanu, Scorpan 1971 - Al. Suceveanu, C-tin Scorpan, Stratigrafia Histriei romane târzii in lumina săpăturilor din 1969 și 1970 in sectorul central, Pontica, 4, 1971, p. 155-172.

Ștefan 1947 -- Gh. Ștefan, Le camp romain de Drajna de Sus, Dacia, XI-XII, 1945-1947, p. 115-144.

Ștefan et alii 1951 - Gh. Ştefan. I. Barnea, D. Protase, V. Vătăşianu, Săpăturile de la Garvăn (Dinogetia) Raiomul Măcin (Galafi), StCerclstorV, 2, 1951, 1, p. 19-49.

Ştefan, Barnea, Mitrea 1962 - Gh. Stcfan, I. Barnea, B. Mitrea, Santierul arheologic Garvăn (Dinogetia), MatCercA, VIII, 1962, p. 675-690. 
Topolcanu 1996 - Fl. Topoleanu, Ceramica romană târzie cu decor ştampilat descoperită la Halmyris, Peuce, XII, 1996, p. 143-168.

Topoleanu 1996a - Fl. Topoleanu, Halmyris - un nouveau centre de production de lampes dans le nord de la Dobroudja (II'-VII's. ap. J.-C.), ReiCretActa 33, Abington, p. 91-94.

Topoleanu 1999 - Fl. Topoleanu, Argamum. Sector "Bazilica II" (1981-1994). Consideratii preliminare privind locuirea romană tầzie, MatCercA S.N., I, 1999, p. 191-201.

Topoleanu 1999a - Fl. Topoleanu, Ceramica romană târzie de la Halmyris. Vasa escaria: formele Hayes 3 şi Hayes 10, Pontica, XXXII, 1999, p. 187-214.

Topoleanu 2000 - Fl. Topoleanu, Ceramica romană şi romano-bizantină de la Halmyris (sec. I-VII d. Ch.), Tulcea, 2000.

Topoleanu 2000a - Fl. Topoleanu, Roman and Roman-Byzantine Pottery from Halmyris. North-Africa Importations and Local Imitations, in Istro-Pontica. Muzeul tulcean la a 50-a aniversare, Tulcea, 257-294.

Topoleanu 2003 - Fl. Topoleanu, Ceramica, in Al. Suceveanu, M. Zahariade, Fl. Topoleanu, Gh. PoenaruBordea, Halmyris, l. Monografie arheologică, Cluj-Napoca, p. 190-245.

Tudor 1953 - D. Tudor, Sucidava, Bucureşti, 1953.

ALEXANDRU BĂDESCU

Muzeul Naţional de Istorie a României,

Calea Victoriei, nr. 12, sector 3, 030026

Bucureşti

alex_bades@yahoo.com 
